\title{
LEVEL II SCOUR ANALYSIS FOR BRIDGE 37 (CONCTH00010037) on TOWN HIGHWAY 1, crossing the MOOSE RIVER, CONCORD, VERMONT
}

U.S. Geological Survey Open-File Report 96-741

Prepared in cooperation with

VERMONT AGENCY OF TRANSPORTATION and

FEDERAL HIGHWAY ADMINISTRATION 


\section{LEVEL II SCOUR ANALYSIS FOR BRIDGE 37 (CONCTH00010037) on TOWN HIGHWAY 1, crossing the MOOSE RIVER, CONCORD, VERMONT \\ By SCOTT A. OLSON}

U.S. Geological Survey Open-File Report 96-741

Prepared in cooperation with

VERMONT AGENCY OF TRANSPORTATION

and

FEDERAL HIGHWAY ADMINISTRATION 


\title{
U.S. DEPARTMENT OF THE INTERIOR BRUCE BABBITT, Secretary
}

\author{
U.S. GEOLOGICAL SURVEY \\ Gordon P. Eaton, Director
}

For additional information write to:

District Chief

U.S. Geological Survey 361 Commerce Way

Pembroke, NH 03275-3718
Copies of this report may be purchased from:

U.S. Geological Survey

Branch of Information Services

Open-File Reports Unit

Box 25286

Denver, CO 80225-0286 


\section{CONTENTS}

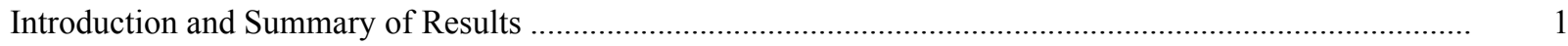

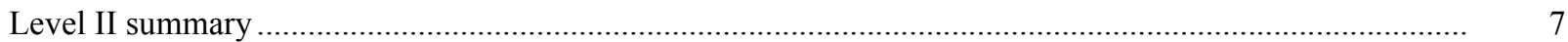

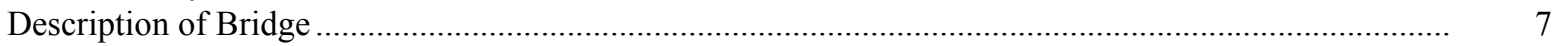

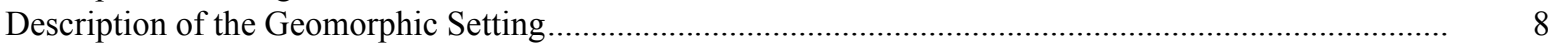

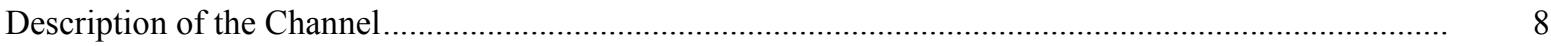

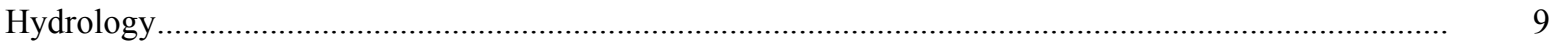

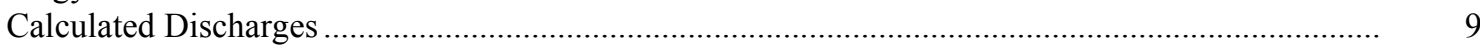

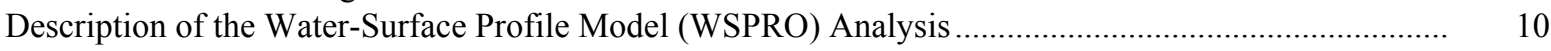

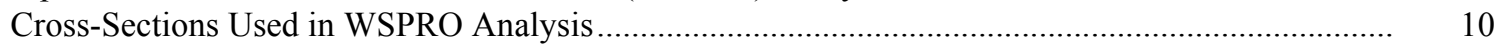

Data and Assumptions Used in WSPRO Model ...................................................................... 11

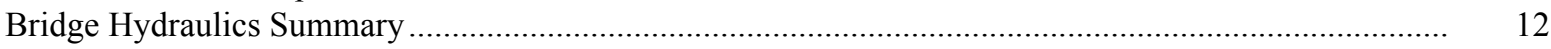

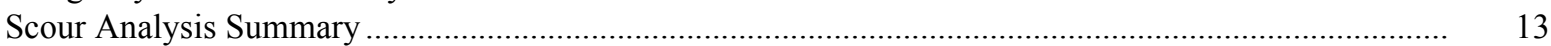

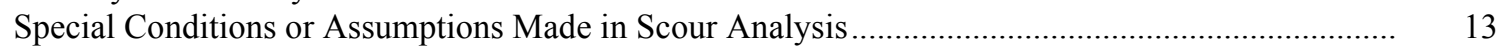

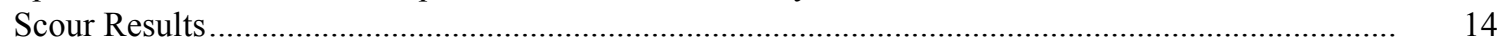

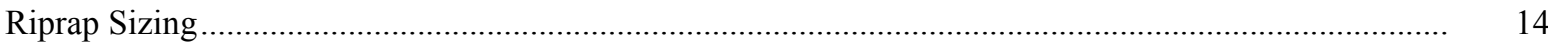

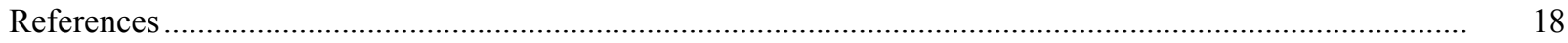

Appendixes:

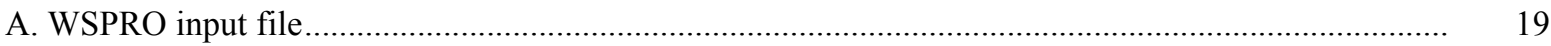

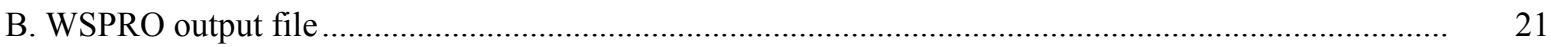

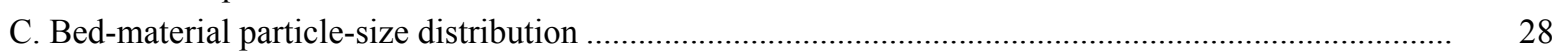

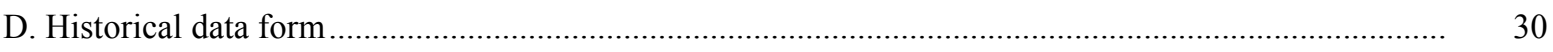

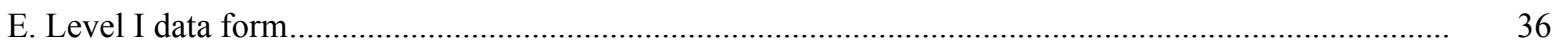

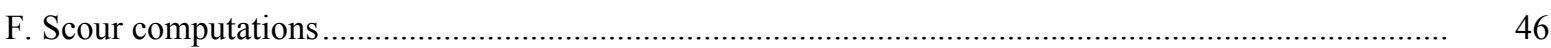

\section{FIGURES}

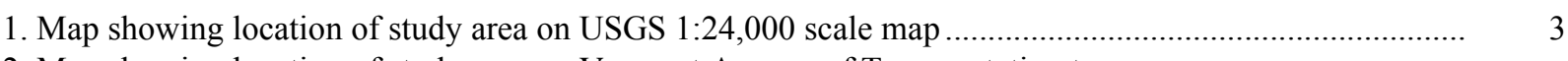

2. Map showing location of study area on Vermont Agency of Transportation town
highway map

3. Structure CONCTH00010037 viewed from upstream (August 16, 1995) …........................................... 5

4. Downstream channel viewed from structure CONCTH00010037 (August 16, 1995)............................ 5

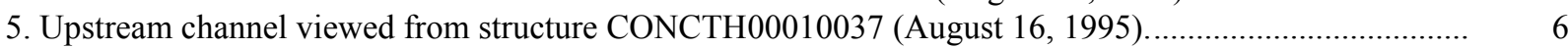

6. Structure CONCTH00010037 viewed from downstream (August 16, 1995). ...................................... 6

7. Water-surface profiles for the 100- and 500-year discharges at structure

CONCTH00010037 on Town Highway 1, crossing the Moose River,

Concord, Vermont.

8. Scour elevations for the 100- and 500-year discharges at structure

CONCTH00010037 on Town Highway 1, crossing the Moose River,

Concord, Vermont.

\section{TABLES}

1. Remaining footing/pile depth at abutments for the 100-year discharge at structure

CONCTH00010037 on Town Highway 1, crossing the Moose River,

Concord, Vermont.....

2. Remaining footing/pile depth at abutments for the 500-year discharge at structure

CONCTH00010037 on Town Highway 1, crossing the Moose River,

Concord, Vermont.

5




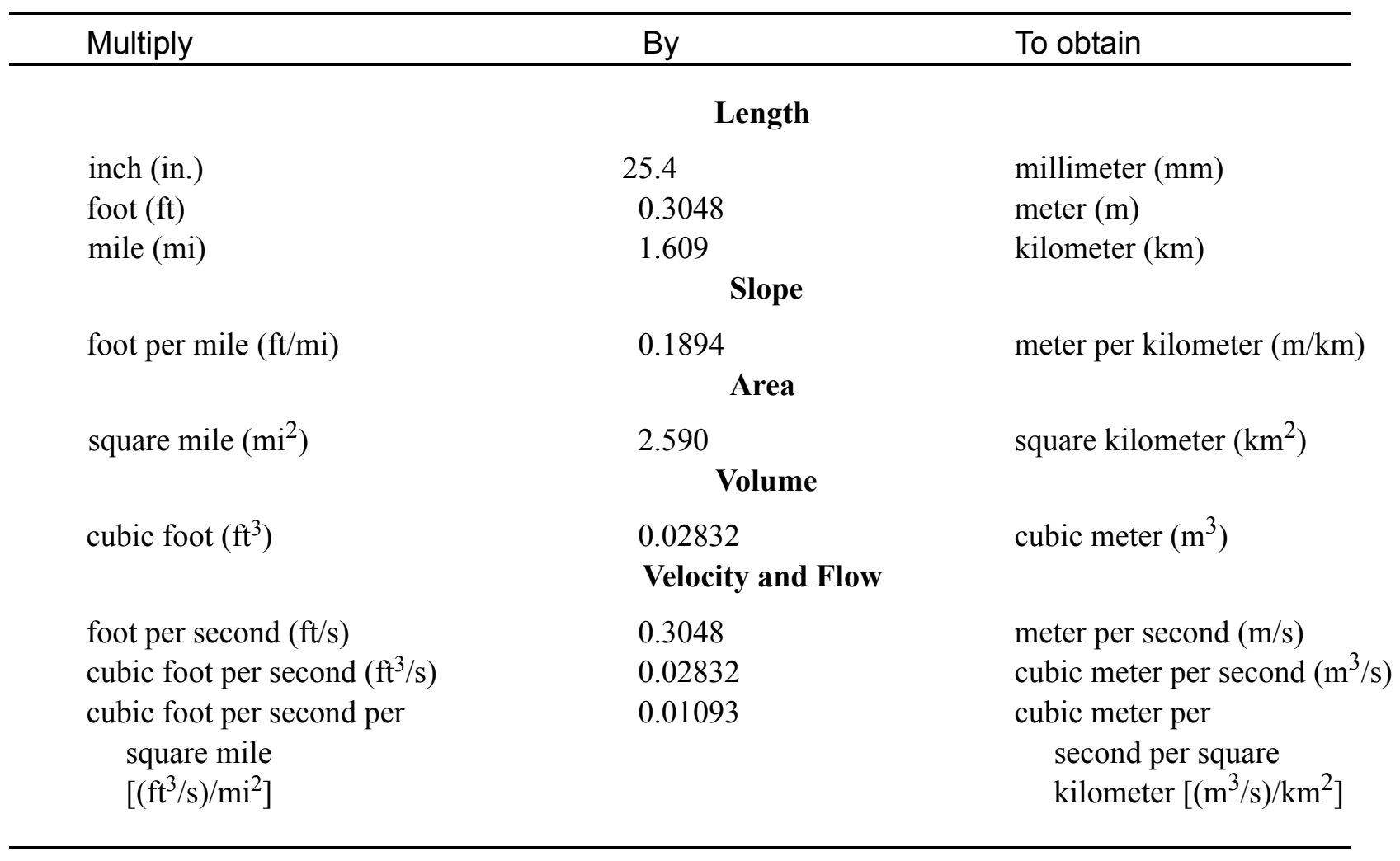

\section{OTHER ABBREVIATIONS}

$\begin{array}{lrlr}\mathrm{BF} & \text { bank full } & \text { LWW } & \text { left wingwall } \\ \mathrm{cfs} & \text { cubic feet per second } & \text { MC } & \text { main channel } \\ \mathrm{D}_{50} & \text { median diameter of bed material } & \text { RAB } & \text { right abutment } \\ \mathrm{DS} & \text { downstream } & \text { RABUT } & \text { face of right abutment } \\ \mathrm{elev} & \text { elevation } & \text { RB } & \text { right bank } \\ \mathrm{f} / \mathrm{p} & \text { flood plain } & \text { ROB } & \text { right overbank } \\ \mathrm{ft}^{2} & \text { square feet } & \text { RWW } & \text { right wingwall } \\ \mathrm{ft} / \mathrm{ft} & \text { feet per foot } & \text { TH } & \text { town highway } \\ \mathrm{JCT} & \text { junction } & \text { UB } & \text { under bridge } \\ \mathrm{LAB} & \text { left abutment } & \text { US } & \text { upstream } \\ \mathrm{LABUT} & \text { face of left abutment } & \text { USGS } & \text { United States Geological Survey } \\ \mathrm{LB} & \text { left bank } & \text { VTAOT Vermont Agency of Transportation } \\ \mathrm{LOB} & \text { left overbank } & \text { WSPRO } & \text { water-surface profile model }\end{array}$

In this report, the words "right" and "left" refer to directions that would be reported by an observer facing downstream. Sea level: In this report, "sea level" refers to the National Geodetic Vertical Datum of 1929-- a geodetic datum derived from a general adjustment of the first-order level nets of the United States and Canada, formerly called Sea Level Datum of 1929.

In the appendices, the above abbreviations may be combined. For example, USLB would represent upstream left bank. 


\title{
LEVEL II SCOUR ANALYSIS FOR BRIDGE 37 (CONCTH00010037) ON TOWN HIGHWAY 1, CROSSING THE MOOSE RIVER, CONCORD, VERMONT
}

\author{
By Scott A. Olson
}

\section{INTRODUCTION AND SUMMARY OF RESULTS}

This report provides the results of a detailed Level II analysis of scour potential at structure CONCTH00010037 on Town Highway 1 crossing the Moose River, Concord, Vermont (figures 1-8). A Level II study is a basic engineering analysis of the site, including a quantitative analysis of stream stability and scour (U.S. Department of Transportation, 1993). Results of a Level I scour investigation also are included in Appendix E of this report. A Level I investigation provides a qualitative geomorphic characterization of the study site. Information on the bridge, gleaned from Vermont Agency of Transportation (VTAOT) files, was compiled prior to conducting Level I and Level II analyses and is found in Appendix D.

Approximately 85 percent of the drainage above the site is in the White Mountain section and 15 percent is in the New England Upland section of the New England physiographic province in northeastern Vermont. The $82.2-\mathrm{mi}^{2}$ drainage area is in a predominantly rural and forested basin. In the vicinity of the study site, the surface cover is forest.

In the study area, the Moose River has an incised, sinuous channel with a slope of approximately $0.01 \mathrm{ft} / \mathrm{ft}$, an average channel top width of $111 \mathrm{ft}$ and an average bank height of $6 \mathrm{ft}$. The channel bed material ranges from gravel to boulder and has a median grain size $\left(\mathrm{D}_{50}\right)$ of $148 \mathrm{~mm}(0.486 \mathrm{ft})$. The geomorphic assessment at the time of the Level I and Level II site visit on August 16, 1995, indicated that the reach was stable.

The Town Highway 1 crossing of the Moose River is a 78-ft-long, two-lane bridge consisting of one 75-foot steel-beam span (Vermont Agency of Transportation, written communication, March 24, 1995). The bridge is supported by vertical, concrete abutments with wingwalls. The channel is skewed approximately 0 degrees to the opening. The opening-skew-to-roadway is also 0 degrees.

Scour protection measure at the site included type- 1 stone fill (less than 12 inches diameter) at each downstream wingwall, type- 2 stone fill (less than 36 inches diameter) at the upstream right wingwall, type- 3 stone fill (less than 48 inches diameter) at the upstream left wingwall, and type- 4 stone fill (less than 60 inches diameter) along the left abutment. Additional details describing conditions at the site are included in the Level II Summary and Appendices D and E. 
Scour depths and rock rip-rap sizes were computed using the general guidelines described in Hydraulic Engineering Circular 18 (Richardson and others, 1995). Total scour at a highway crossing is comprised of three components: 1) long-term streambed degradation; 2) contraction scour (due to accelerated flow caused by a reduction in flow area at a bridge) and; 3) local scour (caused by accelerated flow around piers and abutments). Total scour is the sum of the three components. Equations are available to compute depths for contraction and local scour and a summary of the results of these computations follows.

Contraction scour for all modelled flows was $0.0 \mathrm{ft}$. Abutment scour at the left abutment ranged from 14.3 to $16.1 \mathrm{ft}$. with the worst-case occurring at the incipient-overtopping discharge. Abutment scour at the right abutment ranged from 14.4 to $16.8 \mathrm{ft}$. with the worstcase occurring at the 500-year discharge. Additional information on scour depths and depths to armoring are included in the section titled "Scour Results". Scoured-streambed elevations, based on the calculated scour depths, are presented in tables 1 and 2. A crosssection of the scour computed at the bridge is presented in figure 8. Scour depths were calculated assuming an infinite depth of erosive material and a homogeneous particle-size distribution.

It is generally accepted that the Froehlich equation (abutment scour) gives "excessively conservative estimates of scour depths" (Richardson and others, 1995, p. 47). Usually, computed scour depths are evaluated in combination with other information including (but not limited to) historical performance during flood events, the geomorphic stability assessment, existing scour protection measures, and the results of the hydraulic analyses. Therefore, scour depths adopted by VTAOT may differ from the computed values documented herein. 


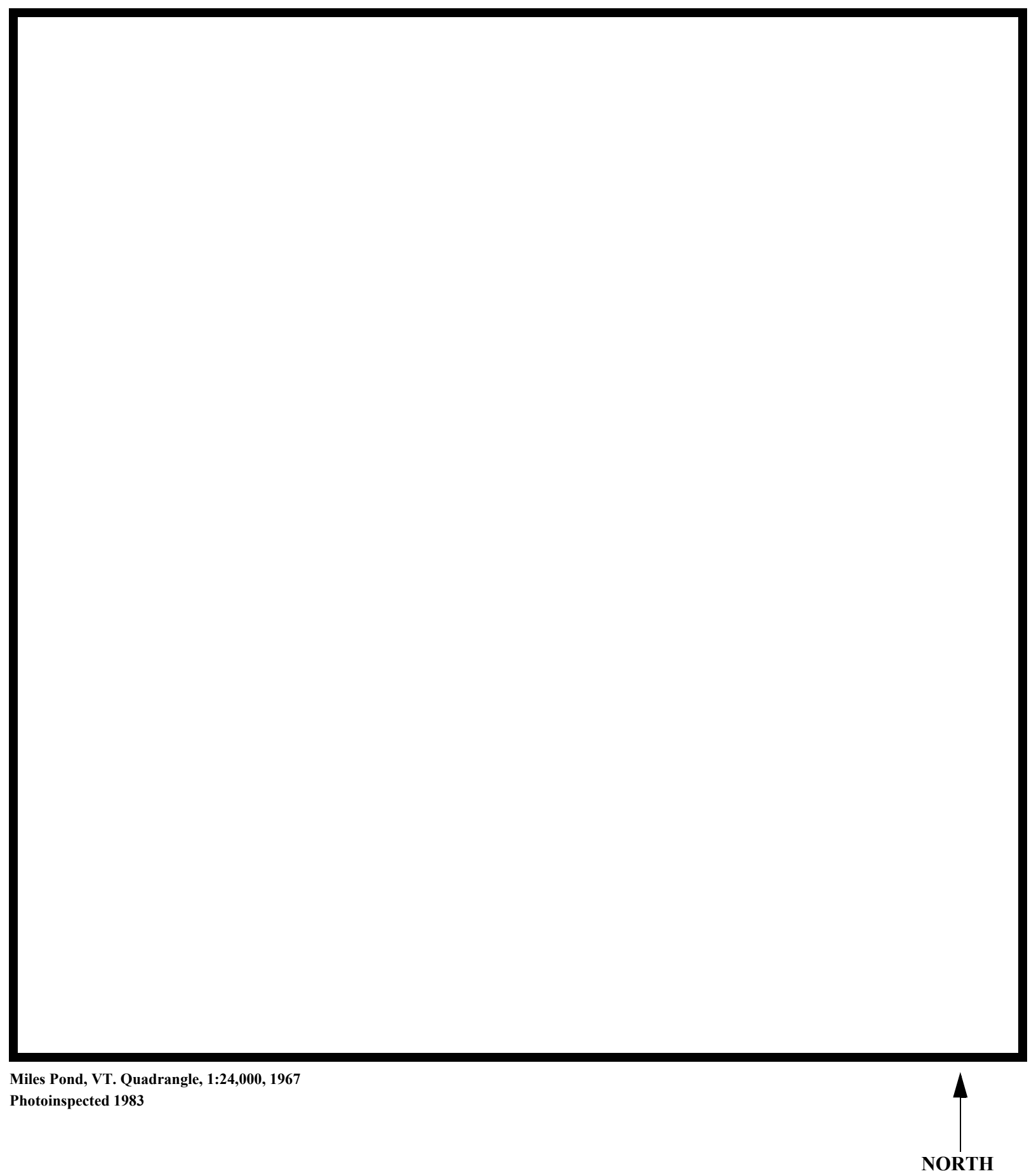

Figure 1. Location of study area on USGS 1:24,000 scale map. 
Figure 2. Location of study area on Vermont Agency of Transportation town highway map. 

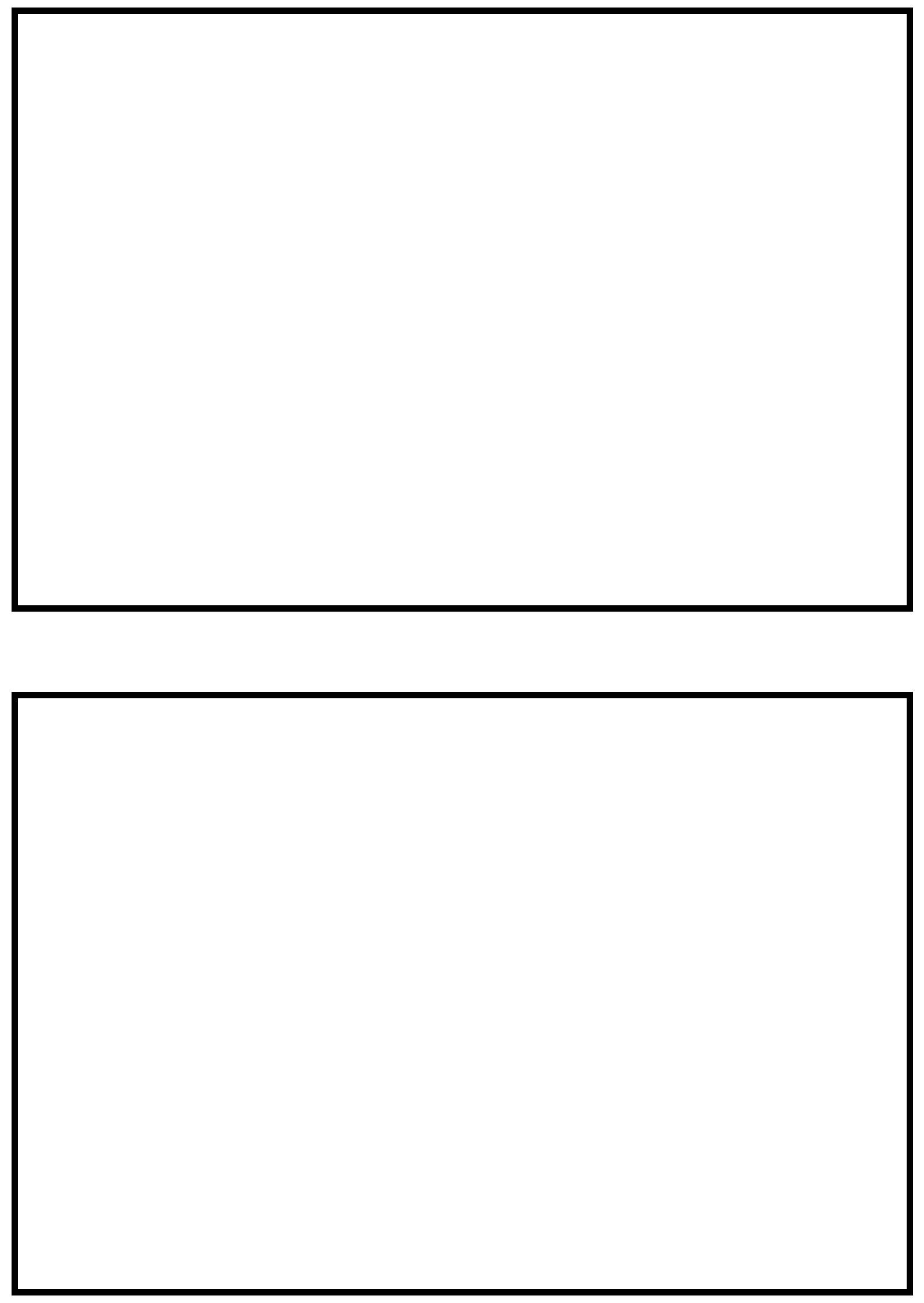

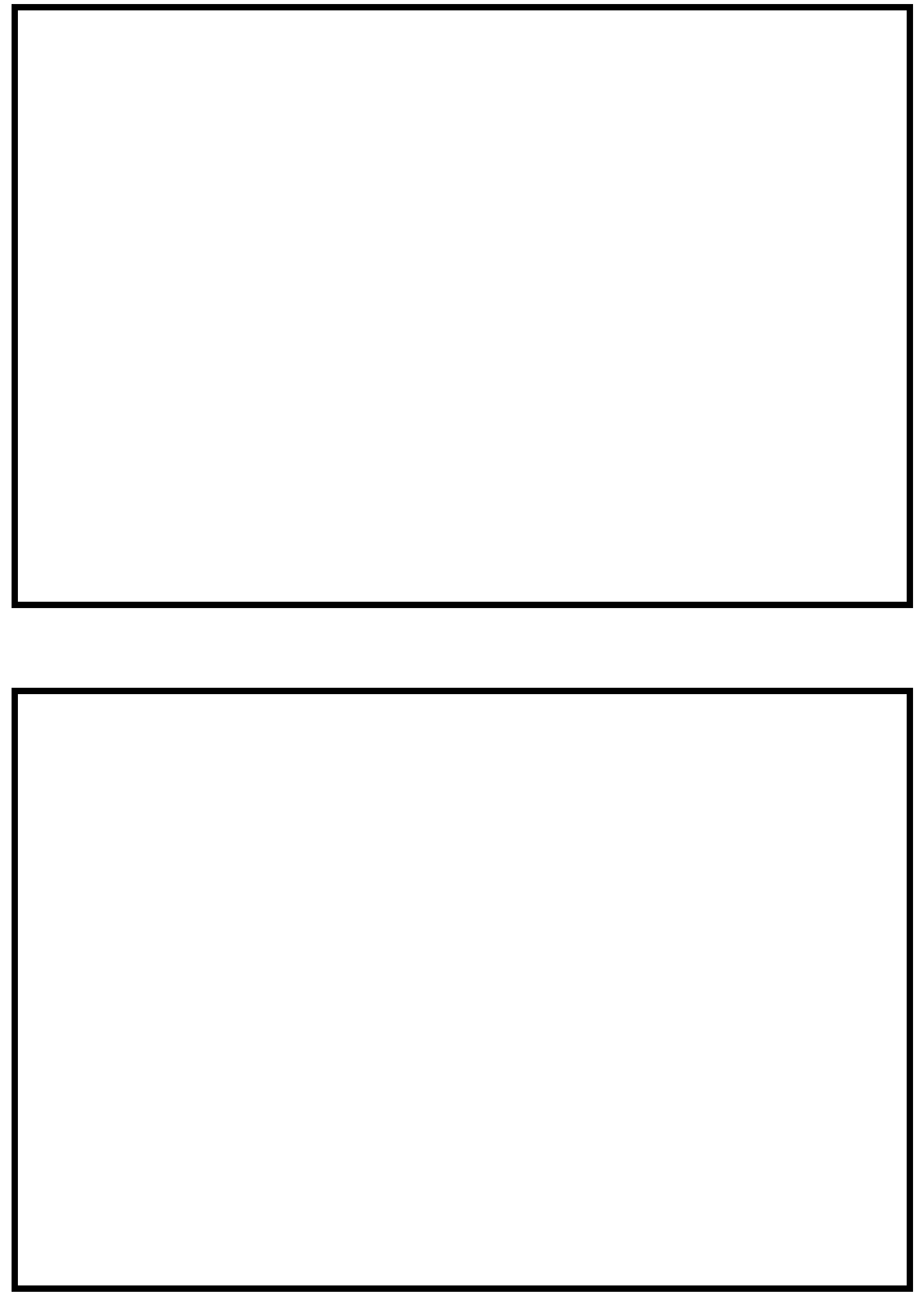


\section{LEVEL II SUMMARY}

\begin{tabular}{llllll} 
Structure Number & CONCTH00010037 & \multirow{2}{*}{ Stream } & \multicolumn{3}{c}{ Moose River } \\
& Road & TH1 & District & 7 \\
County & Essex & Roal & &
\end{tabular}

\section{Description of Bridge}

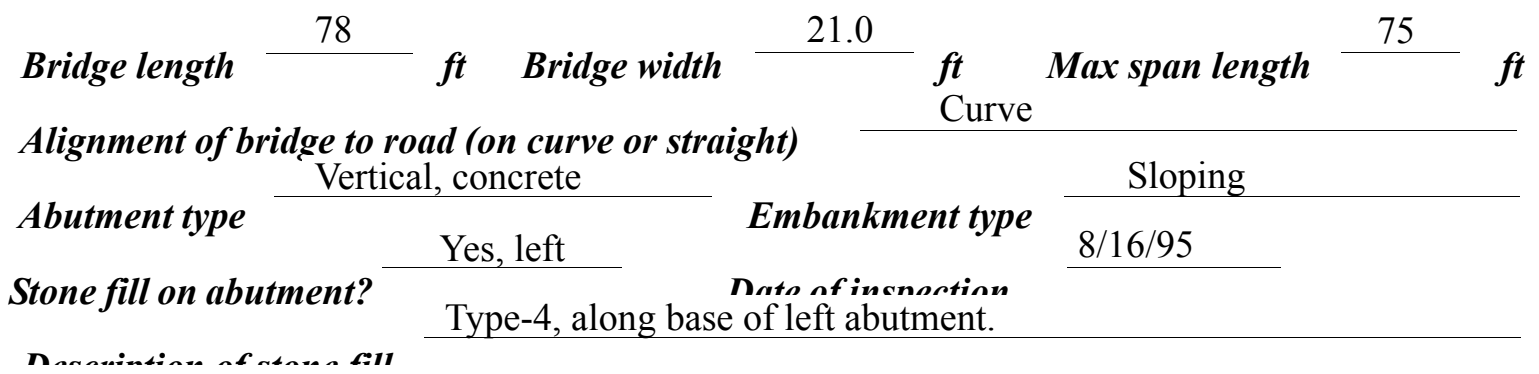

Abutments and wingwalls are concrete.

$\ldots \ldots \ldots$

\section{$\mathrm{N}$} ' survey?

Angle

The reach is straight except for a sharp bend immedjately downstream of the bridge,

Debris accumulation on bridge at time of Level I or Level II site visit:

\begin{tabular}{|c|c|c|c|}
\hline & $\begin{array}{c}\text { Date of insnortion } \\
8 / 16 / 95 \\
\end{array}$ & $\begin{array}{l}\text { Percent of almmunt } \\
\text { blocked inortzontatly }\end{array}$ & $\begin{array}{l}\text { Percent of } \\
\text { blocked verticatty }\end{array}$ \\
\hline & $8 / 16 / 95$ & 0 & 0 \\
\hline & Low. & & \\
\hline
\end{tabular}

\section{Potential for debris}

--, August 16, 1995.

Dosrriho anv fonturos noar ar at tho hridoo that mav affort flow, (includo ahsoryation dato) 


\section{Description of the Geomorphic Setting}

General topography The channel is located within a moderate relief valley with a narrow terrace.

Geomorphic conditions at bridge site: downstream (DS), upstream (US)

Date of inspection $\quad 8 / 16 / 95$

DS left: $\quad$ Steep channel bank to a narrow terrace and moderately sloping overbank.

DS right: $\quad$ Steep channel bank to a narrow terrace and moderately sloping overbank.

US left: $\quad$ Steep channel bank to a narrow terrace and moderately sloping overbank.

US right: $\quad$ Steep channel bank to a narrow terrace and moderately sloping overbank.

\section{Description of the Channel}

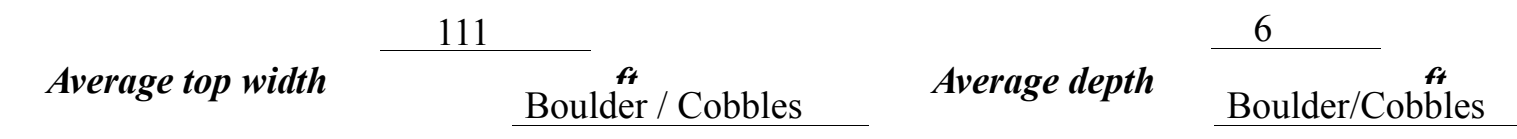

Predominant bed material

Bank material Sinuous but stable

with non-alluvial channel boundaries.

$8 / 16 / 95$

Vegetative co 1 Forested.

DS left: $\quad$ Forested.

DS right: $\quad$ Trees and brush.

US left: $\quad$ Forested.

US right: $\quad$ Y

Do banks appear stable? --, August 16, 1995,

date of observatton.

None,

August 16, 1995.

Describe any obstructions in channel and date of observation. 


\section{Hydrology}

Drainage area $\stackrel{82.2}{\boldsymbol{m i}^{2}}$

Percentage of drainage area in physiographic provinces: (approximate)

Physiographic province/section New England/New England Upland

New England/White Mountain
Percent of drainage area 15

85

Is drainage area considered rural or urban?

Rural urbanization: None

Is there a USGS gage on the stream of interest?

Yes

Moose River at Victory and St. Johnsbury USGS gage description 01134500 and 01135000

USGS gage number $75.2 / 128$

Gage drainage area $\quad \mathrm{mi}^{2}$ No

Is there a lake/p -

Describe any significant

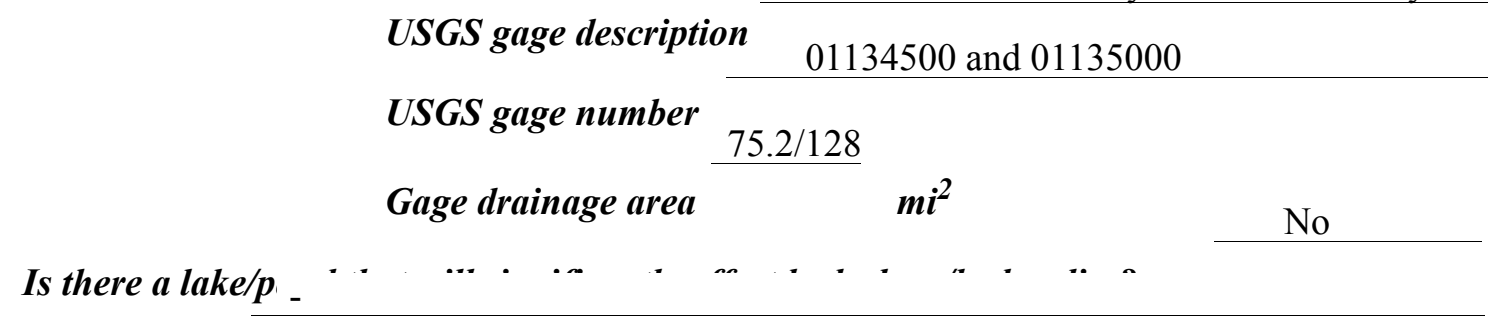

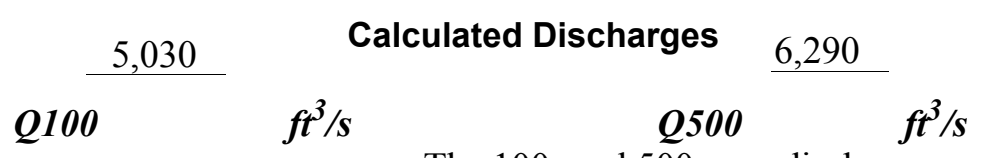

The 100- and 500-year discharges are interpolated

from the 100- and 500-year discharges determined for the upstream (01134500, Moose River at Victory) and downstream (01135000, Moose River at

St. Johnsbury) gages. The 100- and 500- year discharges at the gages were developed using a log-Pearson type-III analysis of annual peak-flow data (Interagency Advisory Committee on Water Data, 1982). 


\section{Description of the Water-Surface Profile Model (WSPRO) Analysis}

Datum for WSPRO analysis (USGS survey, sea level, VTAOT plans)

USGS survey

Datum tie between USGS survey and VTAOT plans

None

Description of reference marks used to determine USGS datum. $\quad$ RM1 is the center of a

chiseled X on top of the downstream end of the left abutment (elev. $899.62 \mathrm{ft}$, arbitrary survey

datum). RM2 is the center of a chiseled $\mathrm{X}$ on top of the upstream end of the right abutment

(elev. $901.41 \mathrm{ft}$, arbitrary survey datum).

\section{Cross-Sections Used in WSPRO Analysis}

\begin{tabular}{|c|c|c|c|}
\hline${ }^{1}$ Cross-section & $\begin{array}{c}\text { Section } \\
\text { Reference } \\
\text { Distance } \\
(\text { SRD) in feet }\end{array}$ & $\begin{array}{c}{ }^{2} \text { Cross-section } \\
\text { development }\end{array}$ & Comments \\
\hline EXITX & -123 & 1 & Exit section \\
\hline FULLV & 0 & 2 & $\begin{array}{l}\text { Downstream Full-valley } \\
\text { section (Templated from } \\
\text { EXITX) }\end{array}$ \\
\hline BRIDG & 0 & 1 & Bridge section \\
\hline RDWAY & 16 & 1 & Road Grade section \\
\hline APTEM & 92 & 1 & $\begin{array}{l}\text { Approach section as sur- } \\
\text { veyed (Used as a tem- } \\
\text { plate) }\end{array}$ \\
\hline APPRO & 102 & 2 & $\begin{array}{l}\text { Modelled Approach sec- } \\
\text { tion (Templated from } \\
\text { APTEM) }\end{array}$ \\
\hline
\end{tabular}

${ }^{1}$ For location of cross-sections see plan-view sketch included with Level I field form, Appendix E. For more detail on how cross-sections were developed see WSPRO input file. 


\section{Data and Assumptions Used in WSPRO Model}

Hydraulic analyses of the reach were done by use of the Federal Highway Administration's WSPRO step-backwater computer program (Shearman and others, 1986, and Shearman, 1990). The analyses reported herein reflect conditions existing at the site at the time of the study. Furthermore, in the development of the model it was necessary to assume no accumulation of debris or ice at the site. Results of the hydraulic model are presented in the Bridge Hydraulic Summary, Appendix B, and figure 7.

Channel roughness factors (Manning's " $n$ ") used in the hydraulic model were estimated using field inspections at each cross section following the general guidelines described by Arcement and Schneider (1989). Final adjustments to the values were made during the modelling of the reach. Channel " $\mathrm{n}$ " values for the reach ranged from 0.055 to 0.065 , and overbank " $\mathrm{n}$ " values ranged from 0.035 to 0.055 .

Normal depth at the exit section (EXITX) was assumed as the starting water surface. This depth was computed by use of the slope-conveyance method outlined in the user's manual for WSPRO (Shearman, 1990). The slope used was $0.0131 \mathrm{ft} / \mathrm{ft}$ which was taken from the 100year water-surface profile downstream of this bridge in the Flood Insurance Study for the Town of Concord (Federal Emergency Management Agency, 1992).

The surveyed approach section (APTEM) was moved along the approach channel slope $(0.028 \mathrm{ft} / \mathrm{ft})$ to establish the modelled approach section (APPRO), one bridge length upstream of the upstream face as recommended by Shearman and others (1986). This approach also provides a consistent method for determining scour variables. 


\section{Bridge Hydraulics Summary}

$\begin{array}{llll}\text { Average bridge embankment elevation } & 900.3 & f t \\ \text { Average low steel elevation } & 896.8 & \boldsymbol{f t}\end{array}$

100-year discharge $\quad 5,030 \quad \mathrm{ft}^{3} / \mathrm{s}$

Water-surface elevation in bridge opening $\quad 893.4 \quad f t$

Road overtopping? ___ N Discharge over road __ _. , s

Area of flow in bridge opening $\quad 405 \quad \mathrm{ft}^{2}$

Average velocity in bridge opening $12.4 \mathrm{ft} / \mathrm{s}$

Maximum WSPRO tube velocity at bridge $\quad 14.6 \mathrm{ft} / \mathrm{s}$

Water-surface elevation at Approach section with bridge 896.9

Water-surface elevation at Approach section without bridge $\quad 897.0$

Amount of backwater caused by bridge $\quad-{ }_{-}$it

500-year discharge $\quad 6,290 \quad \mathrm{ft}^{3} / \mathrm{s}$

Water-surface elevation in bridge opening $\quad 897.1 \mathrm{ft}$

Road overtopping? ___ Y Discharge over road__ $38,7 / s$

Area of flow in bridge opening $\quad 645 \quad \mathrm{ft}^{2}$

Average velocity in bridge opening $\quad 9.7 \mathrm{ft} / \mathrm{s}$

Maximum WSPRO tube velocity at bridge 10.9 /s

Water-surface elevation at Approach section with bridge 899.4

Water-surface elevation at Approach section without bridge $\quad 897.9$

Amount of backwater caused by bridge 1.5 .

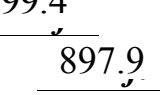

Incipient overtopping discharge $\quad 6,270 \mathrm{ft}^{3} / \mathrm{s}$

Water-surface elevation in bridge opening $\quad 897.1 \quad t$

\begin{tabular}{lll} 
Area of flow in bridge opening & $645 \quad \boldsymbol{f t}^{\mathbf{2}}$ \\
\cline { 2 - 3 } Average velocity in bridge opening & 9.5
\end{tabular}

Average velocity in bridge opening $\quad 9.5 \quad \mathrm{ft} / \mathrm{s}$

Maximum WSPRO tube velocity at bridge $10.9 \mathrm{ft} / \mathrm{s}$

Water-surface elevation at Approach section with bridge

Water-surface elevation at Approach section without bridge

899.3

Amount of backwater caused by bridge $\quad 1.4$, t

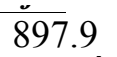




\section{Scour Analysis Summary}

\section{Special Conditions or Assumptions Made in Scour Analysis}

Scour depths were computed using the general guidelines described in Hydraulic Engineering Circular 18 (Richardson and others, 1995). Scour depths were calculated assuming an infinite depth of erosive material and a homogeneous particle-size distribution. The results of the scour analysis are presented in tables 1 and 2 and a graph of the scour depths is presented in figure 8 .

Contraction scour for the 100-year discharge was computed by use of Laursen's clear-water contraction scour equation (Richardson and others, 1995, p. 32, equation 20). The 500-year and incipient roadway-overtopping discharge resulted in orifice flow. Contraction scour at bridges with orifice flow is best estimated by use of the Chang pressure-

flow scour equation (oral communication, J. Sterling Jones, October 4, 1996). Thus, contraction scour for the 500-year and incipient roadway-overtopping discharges was computed by use of the Chang equation (Richardson and others, 1995, p. 145-146) The results of Laursen's clear-water contraction scour for these events were also computed and can be found in appendix F.

Abutment scour was computed by use of the Froehlich equation (Richardson and others, 1995, p. 48, equation 28). Variables for the Froehlich equation include the Froude number of the flow approaching the embankments, the length of the embankment blocking flow, and the depth of flow approaching the embankment less any roadway overtopping. 


\section{Scour Results}

$$
\text { 100-yr discharge 500-yr discharge }
$$

Contraction scour:

Main channel

Live-bed scour

Clear-water scour

Depth to armoring

Left overbank

Right overbank

Local scour:

Abutment scour

Left abutment

Right abutment

Pier scour

Pier 1

Pier 2

Pier 3

(Scour depths in feet)

overtopping discharge
Incipient 


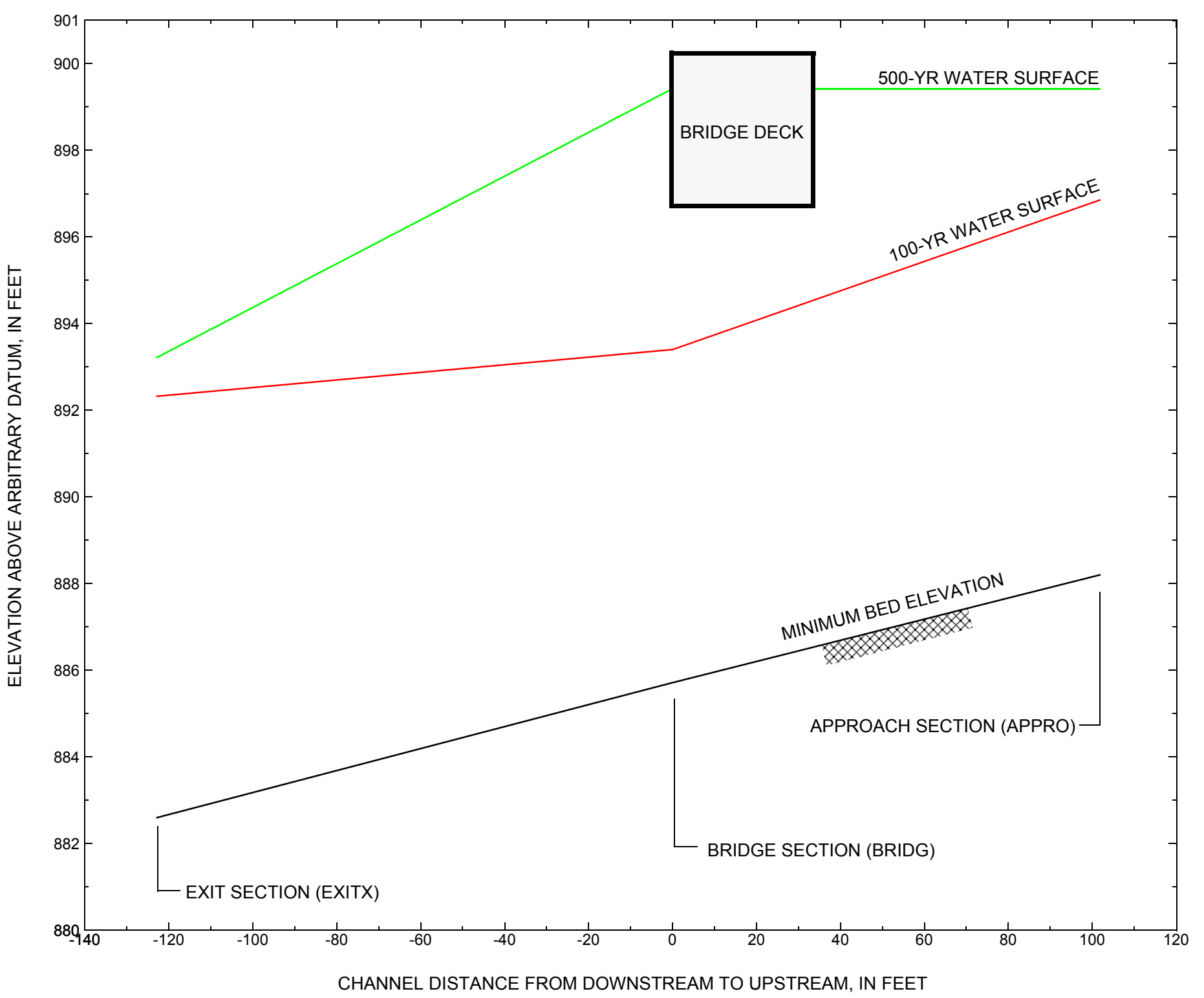

Figure 7. Water-surface profiles for the 100- and 500-yr discharges at structure CONCTH00010037 on Town Highway 1, crossing the Moose River, Concord, Vermont. 


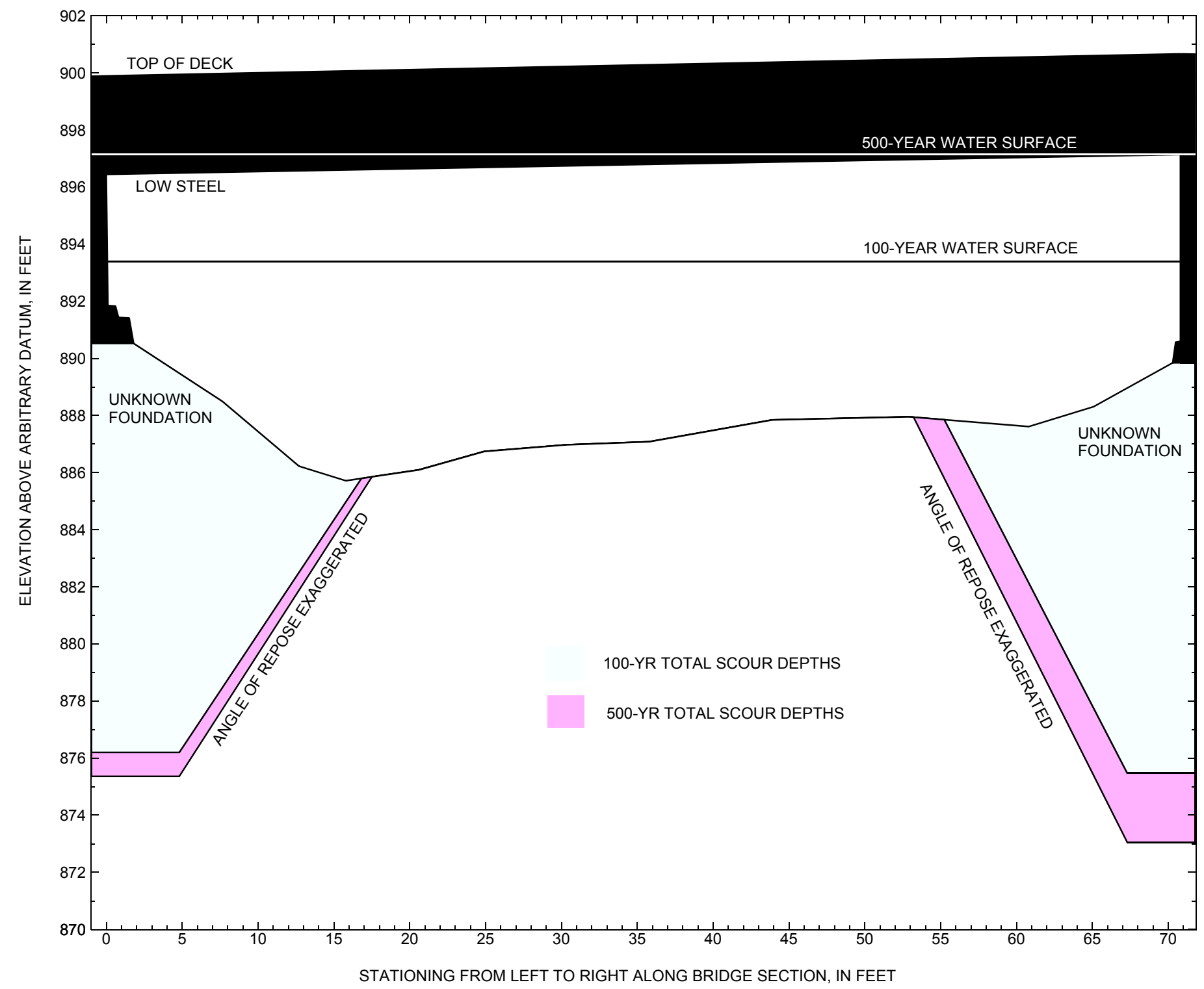

Figure 8. Scour elevations for the 100-yr and 500-yr discharges at structure CONCTH00010037 on Town Highway 1, crossing the Moose River, Concord, Vermont. 
Table 1. Remaining footing/pile depth at abutments for the 100-year discharge at structure CONCTH00010037 on Town Highway 1, crossing the Moose River, Concord, Vermont.

[VTAOT, Vermont Agency of Transportation; --,no data]

\begin{tabular}{|c|c|c|c|c|c|c|c|c|c|c|c|}
\hline Description & Station $^{1}$ & $\begin{array}{l}\text { VTAOT } \\
\text { minimum } \\
\text { low-chord } \\
\text { elevation } \\
\text { (feet) }\end{array}$ & $\begin{array}{l}\text { Surveyed } \\
\text { minimum } \\
\text { low-chord } \\
\text { elevation } \\
\text { (feet) }\end{array}$ & $\begin{array}{l}\text { Bottom of } \\
\text { footing } \\
\text { elevation } \\
\text { (feet) }\end{array}$ & $\begin{array}{l}\text { Channel } \\
\text { elevation at } \\
\text { abutment/ } \\
\text { pier }^{2} \\
\text { (feet) }\end{array}$ & $\begin{array}{l}\text { Contraction } \\
\text { scour depth } \\
\text { (feet) }\end{array}$ & $\begin{array}{l}\text { Abutment } \\
\text { scour } \\
\text { depth } \\
\text { (feet) }\end{array}$ & $\begin{array}{l}\text { Pier } \\
\text { scour } \\
\text { depth } \\
\text { (feet) }\end{array}$ & $\begin{array}{l}\text { Depth of } \\
\text { total scour } \\
\text { (feet) }\end{array}$ & $\begin{array}{c}\text { Elevation of } \\
\text { scour }^{2} \\
\text { (feet) }\end{array}$ & $\begin{array}{c}\text { Remaining } \\
\text { footing/pile } \\
\text { depth } \\
\text { (feet) }\end{array}$ \\
\hline \multicolumn{12}{|c|}{100 -yr. discharge is 5,030 cubic-feet per second } \\
\hline Left abutment & 0.0 & -- & 896.4 & -- & 890.5 & 0.0 & 14.3 & -- & 14.3 & 876.2 & -- \\
\hline Right abutment & 70.8 & -- & 897.1 & -- & 889.8 & 0.0 & 14.4 & -- & 14.4 & 875.4 & -- \\
\hline
\end{tabular}

1.Measured along the face of the most constricting side of the bridge.

2.Arbitrary datum for this study.

Table 2. Remaining footing/pile depth at abutments for the 500-year discharge at structure CONCTH00010037 on Town Highway 1, crossing the Moose River, Concord, Vermont.

[VTAOT, Vermont Agency of Transportation; --, no data]

\begin{tabular}{|c|c|c|c|c|c|c|c|c|c|c|c|}
\hline Description & Station ${ }^{1}$ & $\begin{array}{l}\text { VTAOT } \\
\text { minimum } \\
\text { low-chord } \\
\text { elevation } \\
\text { (feet) }\end{array}$ & $\begin{array}{l}\text { Surveyed } \\
\text { minimum } \\
\text { low-chord } \\
\text { elevation }{ }^{2} \\
\text { (feet) }\end{array}$ & $\begin{array}{l}\text { Bottom of } \\
\text { footing } \\
\text { elevation } \\
\text { (feet) }\end{array}$ & $\begin{array}{c}\text { Channel } \\
\text { elevation at } \\
\text { abutment/ } \\
\text { pier }^{2} \\
\text { (feet) }\end{array}$ & $\begin{array}{l}\text { Contraction } \\
\text { scour depth } \\
\text { (feet) }\end{array}$ & $\begin{array}{l}\text { Abutment } \\
\text { scour } \\
\text { depth } \\
\text { (feet) }\end{array}$ & $\begin{array}{l}\text { Pier } \\
\text { scour } \\
\text { depth } \\
\text { (feet) }\end{array}$ & $\begin{array}{l}\text { Depth of } \\
\text { total scour } \\
\text { (feet) }\end{array}$ & $\begin{array}{c}\text { Elevation of } \\
\text { scour }^{2} \\
\text { (feet) }\end{array}$ & $\begin{array}{c}\text { Remaining } \\
\text { footing/pile } \\
\text { depth } \\
\text { (feet) }\end{array}$ \\
\hline \multicolumn{12}{|c|}{500 -yr. discharge is 6,290 cubic-feet per second } \\
\hline Left abutment & 0.0 & -- & 896.4 & -- & 890.5 & 0.0 & 15.2 & -- & 15.2 & 875.3 & -- \\
\hline Right abutment & 70.8 & -- & 897.1 & -- & 889.8 & 0.0 & 16.8 & -- & 16.8 & 873.0 & -- \\
\hline
\end{tabular}

1.Measured along the face of the most constricting side of the bridge.

2.Arbitrary datum for this study. 


\section{SELECTED REFERENCES}

Arcement, G.J., Jr., and Schneider, V.R., 1989, Guide for selecting Manning's roughness coefficients for natural channels and flood plains: U.S. Geological Survey Water-Supply Paper 2339, 38 p.

Barnes, H.H., Jr., 1967, Roughness characteristics of natural channels: U.S. Geological Survey Water-Supply Paper 1849,213 p.

Benson, M. A., 1962, Factors Influencing the Occurrence of Floods in a Humid Region of Diverse Terrain: U.S. Geological Survey WaterSupply Paper 1580-B, 64 p.

Brown, S.A. and Clyde, E.S., 1989, Design of riprap revetment: Federal Highway Administration Hydraulic Engineering Circular No. 11, Publication FHWA-IP-89-016, 156 p.

Federal Highway Administration, 1983, Runoff estimates for small watersheds and development of sound design: Federal Highway Administration Report FHWA-RD-77-158

Federal Emergency Management Agency, 1992, Flood Insurance Study, Town of Concord, Essex County, Vermont: Washington, D.C., September 30, 1992.

Froehlich, D.C., 1989, Local scour at bridge abutments in Ports, M.A., ed., Hydraulic Engineering--Proceedings of the 1989 National Conference on Hydraulic Engineering: New York, American Society of Civil Engineers, p. 13-18.

Hayes, D.C.,1993, Site selection and collection of bridge-scour data in Delaware, Maryland, and Virginia: U.S. Geological Survey WaterResources Investigation Report 93-4017, 23 p.

Interagency Advisory Committee on Water Data, 1982, Guidelines for determining flood flow frequency: U.S. Geological Survey, Bulletin 17B of the Hydrology Subcommittee, 190 p.

Johnson, C.G. and Tasker, G.D.,1974, Progress report on flood magnitude and frequency of Vermont streams: U.S. Geological Survey OpenFile Report 74-130, 37 p.

Lagasse, P.F., Schall, J.D., Johnson, F., Richardson, E.V., Chang, F., 1995, Stream Stability at Highway Structures: Federal Highway Administration Hydraulic Engineering Circular No. 20, Publication FHWA-IP-90-014, 144 p.

Laursen, E.M., 1960, Scour at bridge crossings: Journal of the Hydraulics Division, American Society of Civil Engineers, v. 86, no. HY2, p. 39-53.

Potter, W. D., 1957a, Peak rates of runoff in the Adirondack, White Mountains, and Maine woods area, Bureau of Public Roads

Potter, W. D., 1957b, Peak rates of runoff in the New England Hill and Lowland area, Bureau of Public Roads

Richardson, E.V. and Davis, S.R., 1995, Evaluating scour at bridges: Federal Highway Administration Hydraulic Engineering Circular No. 18, Publication FHWA-IP-90-017, 204 p.

Richardson, E.V., Simons, D.B., and Julien, P.Y., 1990, Highways in the river environment: Federal Highway Administration Publication FHWA-HI-90-016.

Ritter, D.F., 1984, Process Geomorphology: W.C. Brown Co., Debuque, Iowa, 603 p.

Shearman, J.O., 1990, User's manual for WSPRO--a computer model for water surface profile computations: Federal Highway Administration Publication FHWA-IP-89-027, 187 p.

Shearman, J.O., Kirby, W.H., Schneider, V.R., and Flippo, H.N., 1986, Bridge waterways analysis model; research report: Federal Highway Administration Publication FHWA-RD-86-108, 112 p.

Talbot, A.N., 1887, The determination of water-way for bridges and culverts.

U.S. Department of Transportation, 1993, Stream stability and scour at highway bridges, Participant Workbook: Federal Highway Administration Publication FHWA HI-91-011.

U.S. Geological Survey, 1967, Miles Pond, Vermont 7.5 Minute Series quadrangle map: U.S. Geological Survey Topographic Maps, Photoinspected 1983, Scale 1:24,000. 


\section{APPENDIX A: \\ WSPRO INPUT FILE}




\section{WSPRO INPUT FILE}

GR

GR

GR

GR

GR

$\mathrm{N}$

SA

XS

BR

GR

GR

GR

GR

GR

GR

$\mathrm{N}$

CD

XR

GR

GR

GR

*

$\mathrm{XT}$

GR

GR

GR

GR

GR

GR

GR

*

AS

$\mathrm{N}$

SA

HP 1 BRIDG

HP 2 BRIDG

HP 1 APPRO

HP 2 APPRO

HP 1 BRIDG

HP 2 BRIDG

HP 2 RDWAY

U.S. Geological Survey WSPRO Input File conc037.wsp Hydraulic analysis for structure CONCTH00010037 Date: 24-JUN-96 Hydraulic Analysis of CONC037 over the Moose River SAO

$62930 \quad 552553551516 \quad 17 \quad 13 \quad 3 * \begin{array}{llllllllll}15 & 14 & 23 & 21 & 11 & 12 & 4 & 7 & 3\end{array}$

503062906270

0.01310 .01310 .0131

$\operatorname{EXITX} \quad-123$

$-114.6,907.72 \quad-81.1,898.38$

$-33.7,892.01-10.8,888.15$

$21.0,883.06 \quad 27.5,882.59$

$54.8,886.16 \quad 74.3,892.78$

$101.4,898.20110 .6,897.33$

0.035

$-41.9$ 0.065

84.4

0.055

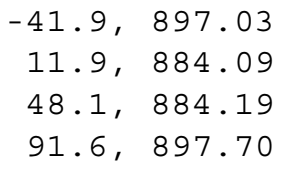

$0.8,891.43$

$12.7,886.22$

$30.3,886.97$

$60.8,887.61$

$70.8,890.59$
$65.1,888.31$

$70.8,897.13$

0.055

140 * * 488
$1.8,890.52$

$20.6,886.09$

$43.9,887.84$

$70.3,889.84$

$0.0,896.44$

$-82.1,898.76$

$73.8,901.31$

$289.5,907.59$

$228.0,904.63$

92

$-98.1,908.22$

$-29.8,900.97$

$-86.7,906.97$

$-18.0,895.83$

$7.0,888.44$

$0.4,889.11$

$24.8,888.49$

$47.1,889.67$

$66.2,889.09$

$130.8,900.10$
$31.1,888.93$

$47.4,889.23$

$77.0,890.03$

$182.3,902.67$
$-56.4,899.29$

$73.9,900.66$

$359.7,917.65$

$-61.7,901.42$

$-6.3,889.97$

$13.6,887.92$

$31.3,890.02$

$54.0,889.17$

$94.7,896.43$

$236.1,912.49$
$-2.9,899.89$ $125.2,901.60$

$-51.6,901.31$

$-5.7,889.31$

$16.7,887.97$

$40.7,891.07$

$60.6,888.90$

$120.6,899.18$ 


\section{APPENDIX B: \\ WSPRO OUTPUT FILE}


WSPRO OUTPUT FILE

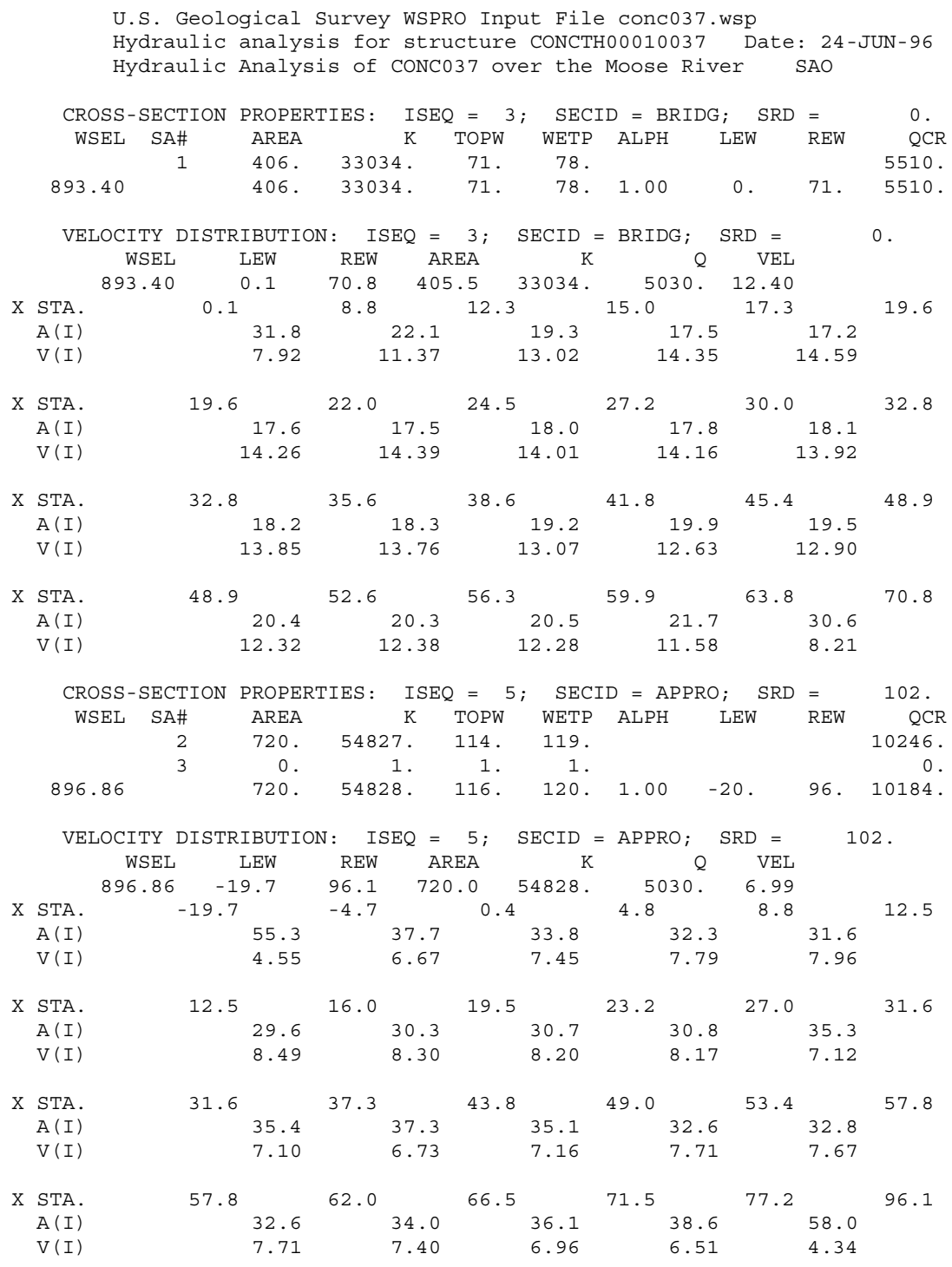


WSPRO OUTPUT FILE (continued)

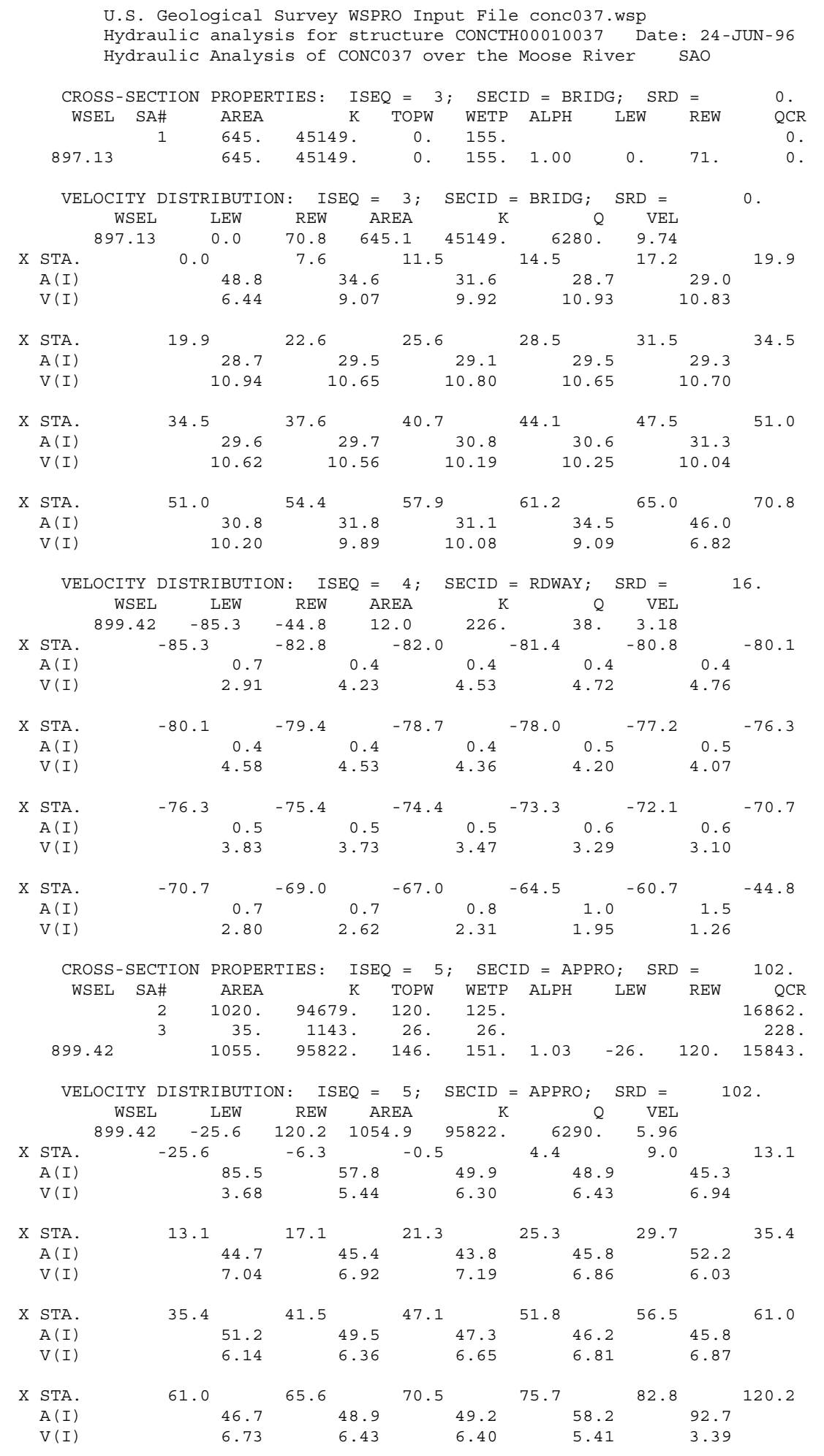


WSPRO OUTPUT FILE (continued)

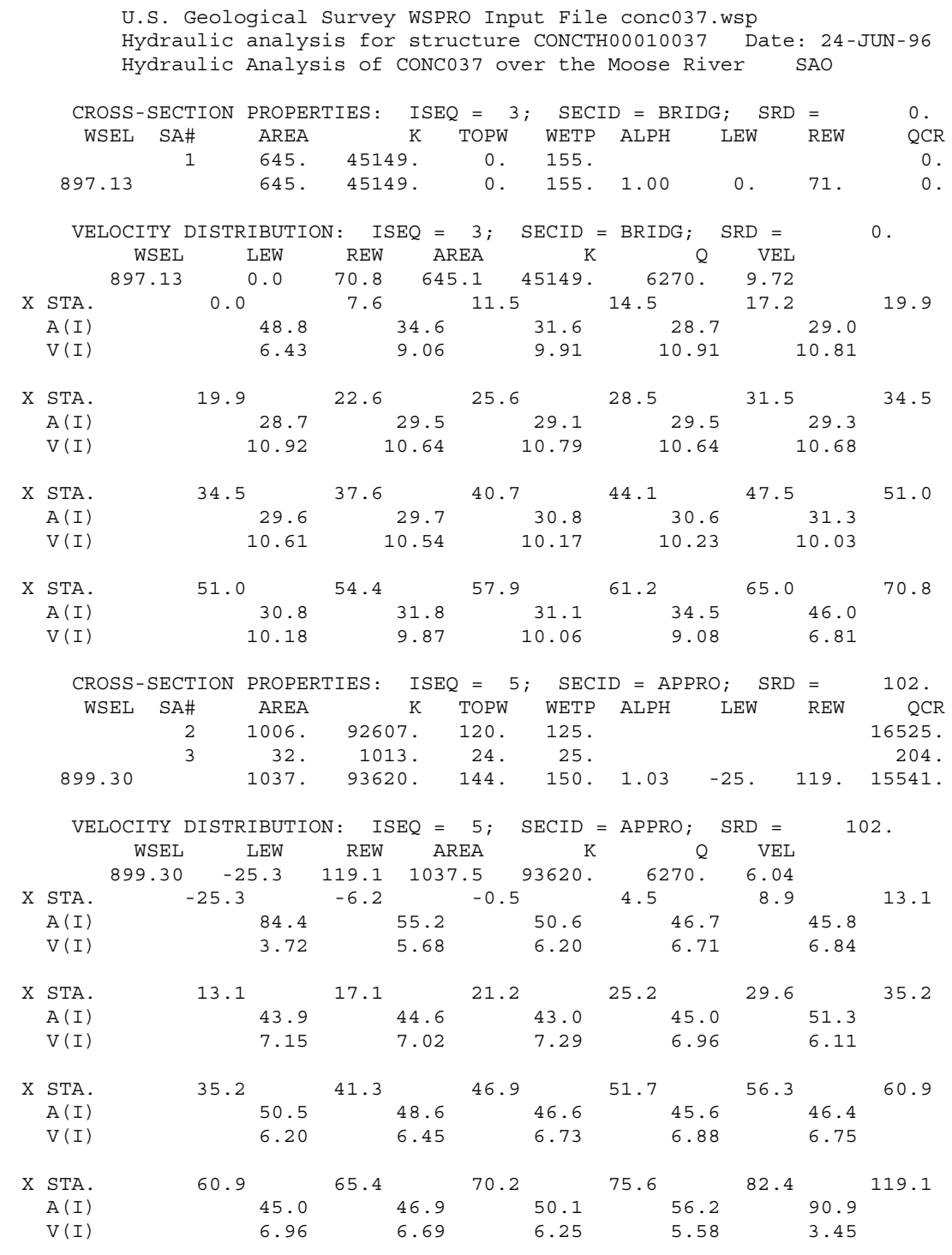


WSPRO OUTPUT FILE (continued)

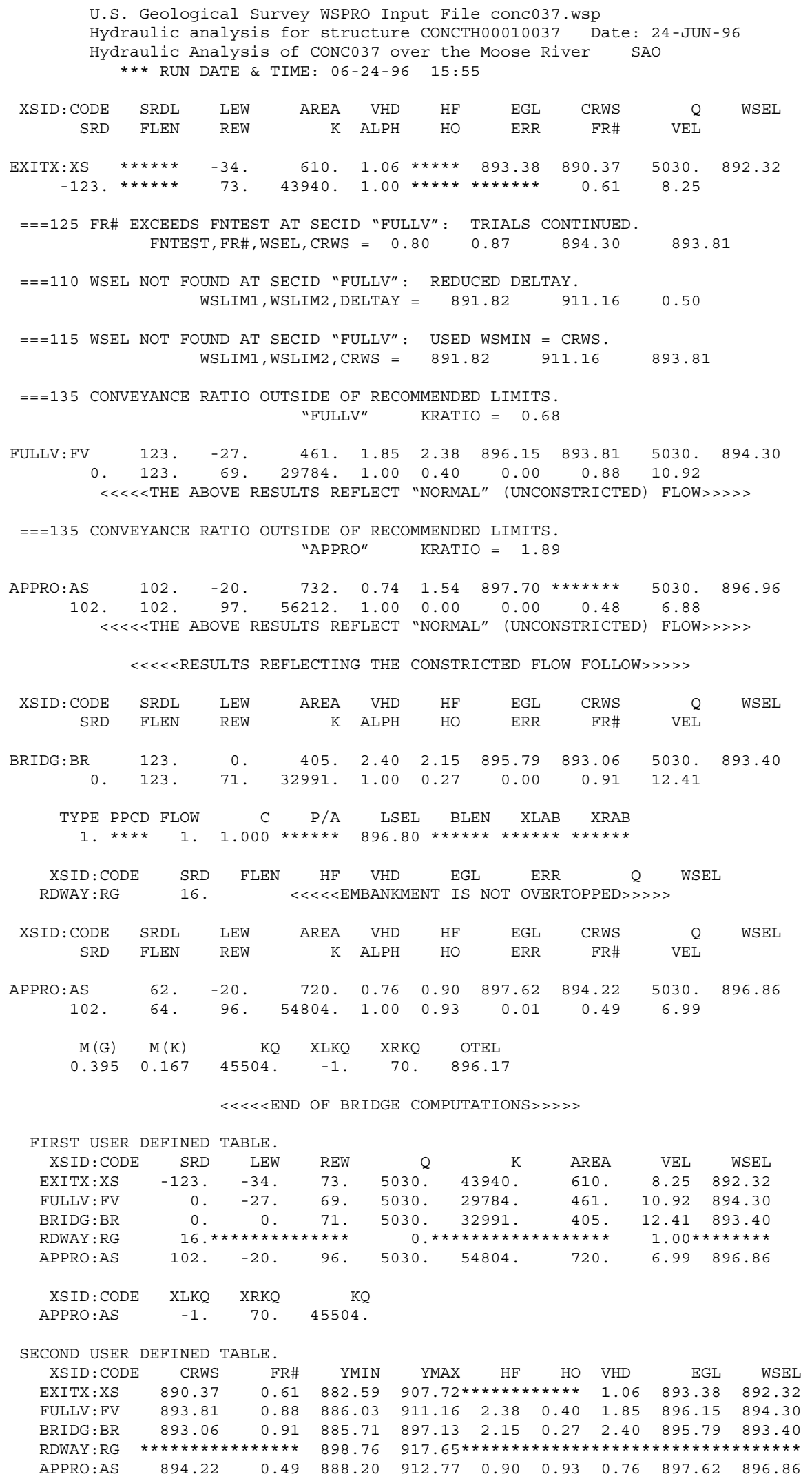


WSPRO OUTPUT FILE (continued)

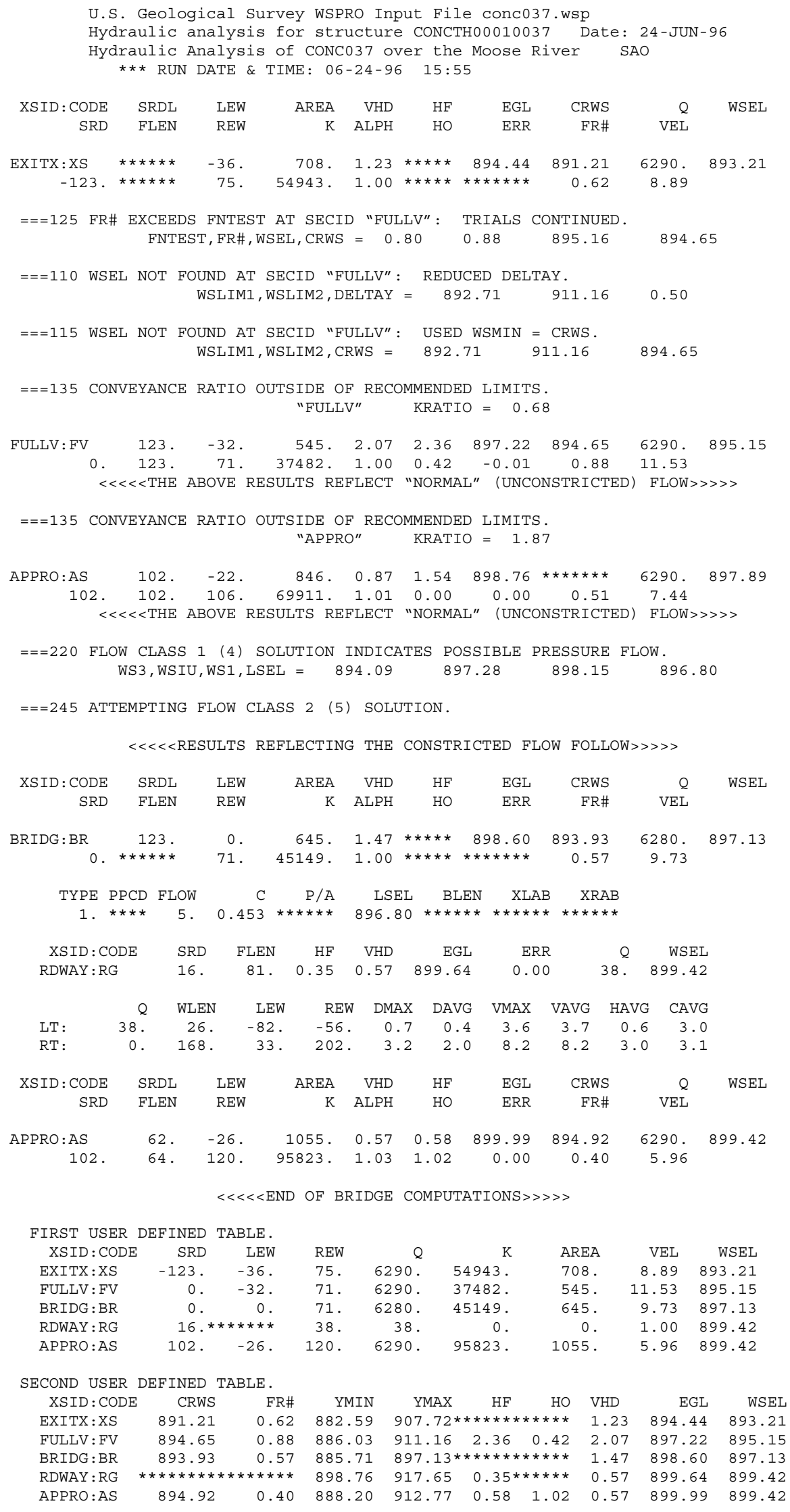


WSPRO OUTPUT FILE (continued)

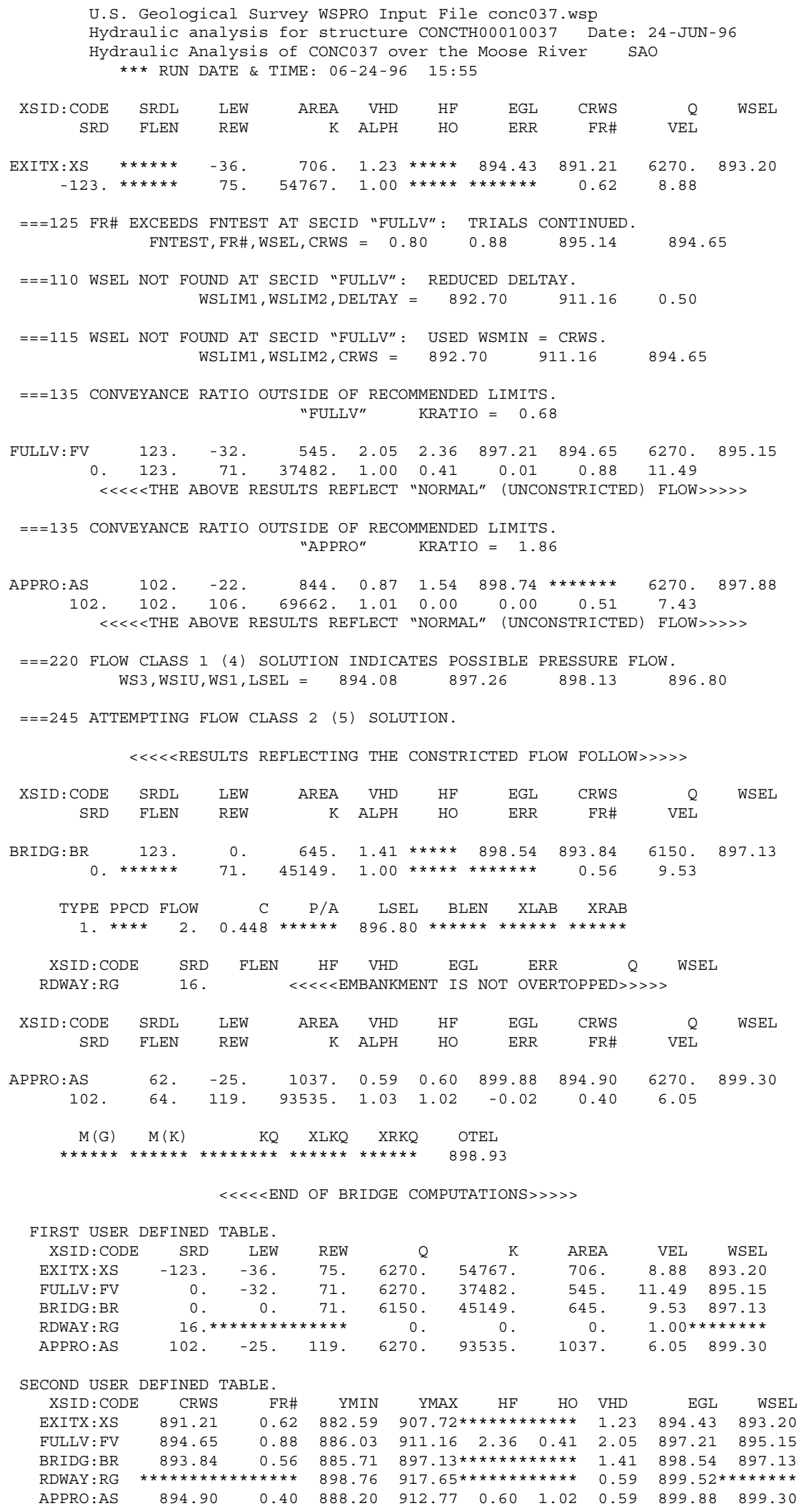




\section{APPENDIX C:}

\section{BED-MATERIAL PARTICAL-SIZE DISTRIBUTION}




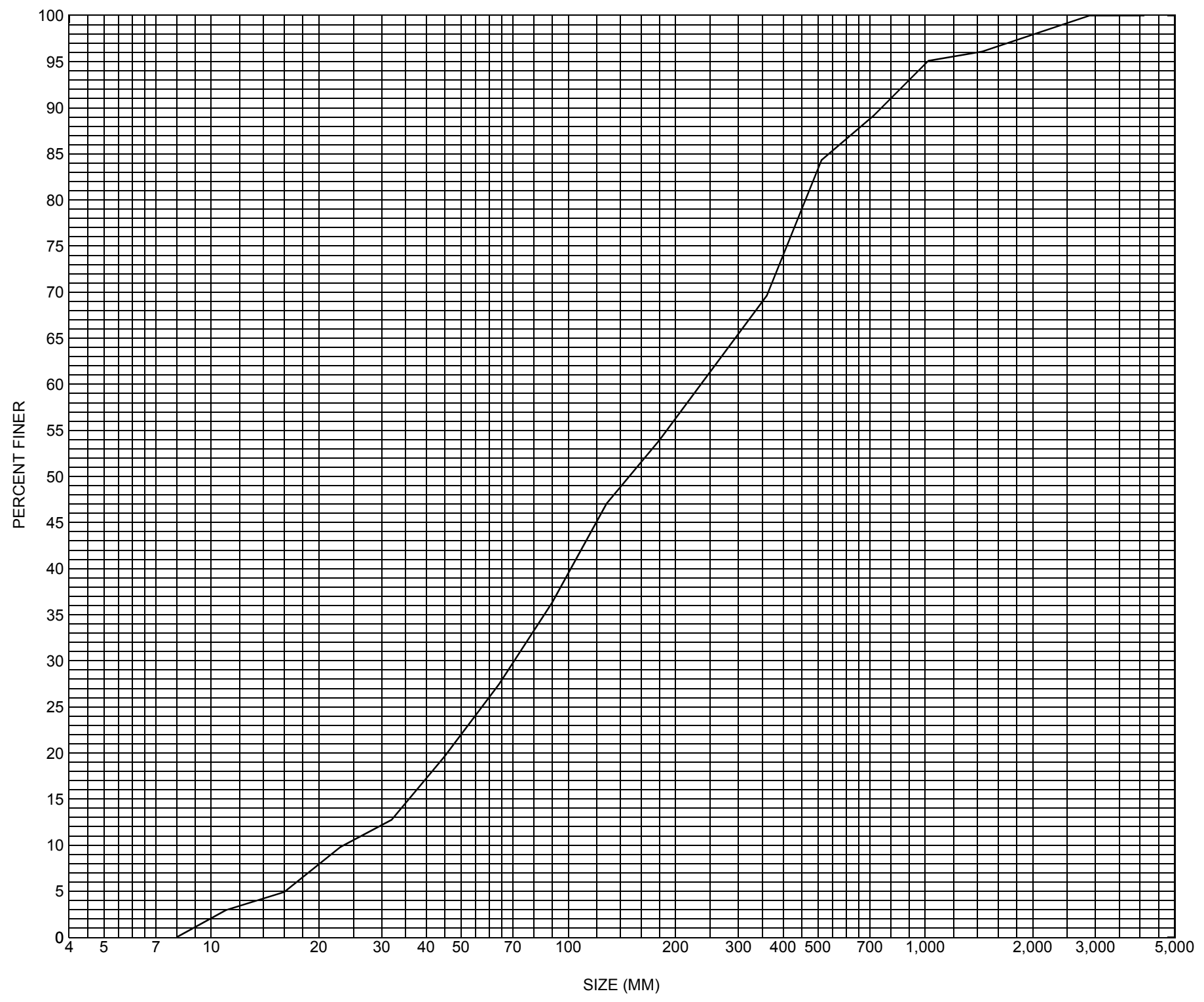

Appendix C. Bed material particle-size distribution for a pebble count in the channel approach of structure CONCTH00010037, in Concord, Vermont. 


\section{APPENDIX D: \\ HISTORICAL DATA FORM}




\section{Structure Number CONCTH00010037}

\section{General Location Descriptive}

Data collected by (First Initial, Full last name) $\mathbf{E}$. BOEHMLER

Date $(M M / D D / Y Y) \_\mathbf{0 3} / \underline{24} / \underline{95}$

Highway District Number (I - 2; nn) $\mathbf{0 7}$

Town (FIPS place code; I - 4; nnnnn) $\mathbf{1 5 2 5 0}$

Waterway (I - 6) MOOSE RIVER

Route Number TH001

Topographic Map Miles.Pond

Latitude (I - 16; nnnn.n) $\mathbf{4 4 2 9 0}$
County (FIPS county code; I - 3; nnn)

Mile marker (I - 11; nnn.nnn) $\mathbf{0 0 1 1 9 0}$

Road Name (I - 7): -

Vicinity (I - 9) FAS 277 1.2 MI N JCT U.S.2

Hydrologic Unit Code: $\mathbf{0 1 0 8 0 1 0 2}$

Longitude (i - 17; nnnnn.n) 71518

\section{Select Federal Inventory Codes}

FHWA Structure Number (I - 8) $\mathbf{2 0 0 2 7 7 0 0 3 7 0 5 0 7}$

Maintenance responsibility $(I-21 ; n n) \_$03 $\quad$ Maximum span length $(I-48 ; n n n n) \underline{\mathbf{0 0 7 5}}$

Year built (I - 27; YYYY) 1933

Structure length (I - 49; nnnnnn) $\underline{\mathbf{0 0 0 0 7 8}}$

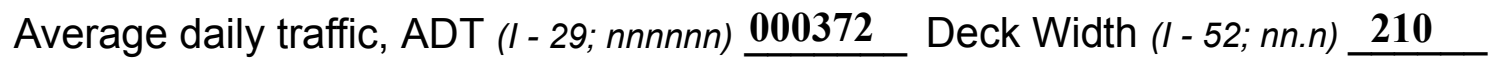

Year of ADT (I - 30; YY) $\underline{91}$

Channel \& Protection $(I-61 ; n) \underline{7}$

Opening skew to Roadway $(I-34 ; n n) \quad \mathbf{0 0}$

Waterway adequacy $(I-71 ; n) \quad 5$

Operational status $(I-41 ; X) \quad \mathbf{A}$

Underwater Inspection Frequency $(I-92 B ; X Y Y) \_\mathbf{N}$

Structure type (I - 43; nnn) $\mathbf{3 0 2}$

Year Reconstructed (I - 106) $\mathbf{0 0 0 0}$

Approach span structure type $(I-44 ; n n n) \quad \mathbf{0 0 0}$

Clear span (nnn.n ft) _

Number of spans (I - 45; nnn) $\underline{\mathbf{0 0 1}}$

Vertical clearance from streambed (nnn.n ft) $\underline{\mathbf{0 0 9 . 0}}$

Number of approach spans (I - 46; nnnn) $\mathbf{0 0 0 0}$ Waterway of full opening $\left(n n n . n \mathrm{ft}^{2}\right)$

Comments:

The structural inspection report of 5/12/94 indicates the structure is a steel stringer type bridge with a concrete deck and an asphalt roadway surface. The abutments and wingwalls are concrete. On the left abutment an older portion of the footing is exposed. A new concrete subfooting is present in front of the older footing. The right abutment footing also is exposed for nearly its entire length. The footing concrete has some minor scaling reported. All four wingwalls are new virtually. The downstream end of the right abutment footing was poured directly on top of a few massive granite boulders. Both abutments reportedly are protected with heavy stone fill. The channel consists mainly of gravel (Continued, page 33) 


\section{Bridge Hydrologic Data}

Is there hydrologic data available? $\underline{\mathbf{N}}$ if No, type ctrl-n $h \quad$ VTAOT Drainage area $\left(m i^{2}\right)$ : -

Terrain character:

Stream character \& type: -

Streambed material:

Discharge Data (cfs):

$$
\begin{aligned}
& Q_{2.33}- \\
& Q_{50}-
\end{aligned}
$$

Record flood date $(M M / D D / Y Y)$ :

Estimated Discharge (cfs): Ice conditions (Heavy, Moderate, Light) : -

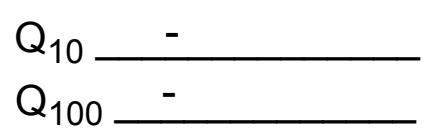

$$
\begin{aligned}
& Q_{25}- \\
& Q_{500}-
\end{aligned}
$$

Water surface elevation $(f t):-$

The stage increases to maximum highwater elevation (Rapidly, Not rapidly):

The stream response is (Flashy, Not flashy):

Describe any significant site conditions upstream or downstream that may influence the stream's stage: -

Watershed storage area (in percent): _ _ \%

The watershed storage area is: - (1-mainly at the headwaters; 2- uniformly distributed; 3-immediatly upstream oi the site)

Water Surface Elevation Estimates for Existing Structure:

\begin{tabular}{|l|l|l|l|l|l|}
\hline Peak discharge frequency & $Q_{2.33}$ & $Q_{10}$ & $Q_{25}$ & $Q_{50}$ & $Q_{100}$ \\
Water surface elevation (ft)) & - & - & - & - & - \\
Velocity (ft/sec) & - & - & - & - & - \\
\hline
\end{tabular}

Long term stream bed changes: -

Is the roadway overtopped below the $\mathrm{Q}_{100}$ ? (Yes, No, Unknown): $\mathbf{U}$ Frequency: Relief Elevation (ft): Discharge over roadway at $Q_{100}\left(f^{3} / \mathrm{sec}\right)$ :

Are there other structures nearby? (Yes, No, Unknown): $\underline{\mathbf{U}}$ Upstream distance (miles): Town: If No or Unknown, type ctrl-n os Highway No. : Structure No. : Year Built:

Clear span (ft): Clear Height $(f t)$ : Full Waterway $\left(f^{2}\right)$ : 
Downstream distance (miles): Town: Year Built:

Highway No. : Structure No. : Structure Type:

Clear span $(f t):$ Clear Height $(f t)$ : Full Waterway $\left(f^{2}\right):$

Comments:

and boulders. The channel proceeds straight through the crossing. The water is brackish. The report notes some previous undermining at the left abutment, but no settling occurred apparently before the subfooting was installed. There is no streambank erosion or debris accumulation problems indicated.

\section{USGS Watershed Data}

Watershed Hydrographic Data

Drainage area $(D A) \quad 82.169 \mathrm{mi}^{2}$ Lake and pond area $\underline{3.01}$ $\mathrm{mi}^{2}$

Watershed storage (ST)

Bridge site elevation 1013

Main channel length 22.03 3.66 $\%$

$10 \%$ channel length elevation $\mathbf{1 0 7 5}$ $\mathrm{ft} \quad 85 \%$ channel length elevation 2060 $\mathrm{ft}$

Main channel slope $(S) \quad \mathbf{5 9 . 6 1 6} \mathrm{ft} / \mathrm{mi}$

Watershed Precipitation Data

Average site precipitation in Average headwater precipitation in

Maximum 2yr-24hr precipitation event $(124,2)$ in

Average seasonal snowfall (Sn) $\mathrm{ft}$ 


\section{Bridge Plan Data}

Are plans available? If no, type ctrl-n pl

Project Number --

Minimum channel bed elevation: --

Low superstructure elevation: USLAB -DSLAB --

Benchmark location description:

NO BENCHMARK INFORMATION

Reference Point (MSL, Arbitrary, Other):

Datum (NAD27, NAD83, Other):

Foundation Type: 4

If 1: Footing Thickness

If 2: Pile Type: (1-Wood; 2-Steel or metal; 3-Concrete)

(1-Spreadfooting; 2-Pile; 3- Gravity; 4-Unknown) USRAB -DSRAB --

If 3: Footing bottom elevation:

Is boring information available? $\mathbf{N}$ If no, type ctrl-n bi Number of borings taken:

Foundation Material Type: $\mathbf{3}$ (1-regolith, 2-bedrock, 3-unknown)

Briefly describe material at foundation bottom elevation or around piles:

NO FOUNDATION MATERIAL INFORMATION

Comments:

NO PLANS. 


\section{Cross-sectional Data}

Is cross-sectional data available? $\mathbf{N}$ If no, type ctrl-n xs

Source (FEMA, VTAOT, Other)? -

Comments: NO CROSS SECTION INFORMATION

\begin{tabular}{|l|l|l|l|l|l|l|l|l|l|l|l|}
\hline Station & - & - & - & - & - & - & - & - & - & - & - \\
\hline Feature & - & - & - & - & - & - & - & - & - & - & - \\
\hline $\begin{array}{l}\text { Low cord } \\
\text { elevation }\end{array}$ & - & - & - & - & - & - & - & - & - & - & - \\
\hline $\begin{array}{l}\text { Bed } \\
\text { elevation }\end{array}$ & - & - & - & - & - & - & - & - & - & - & - \\
\hline $\begin{array}{l}\text { Low cord to } \\
\text { bed length }\end{array}$ & - & - & - & - & - & - & - & - & - & - & - \\
\hline Station & - & - & - & - & - & - & - & - & - & - & - \\
\hline Feature & - & - & - & - & - & - & - & - & - & - & - \\
\hline $\begin{array}{l}\text { Low cord } \\
\text { elevation }\end{array}$ & - & - & - & - & - & - & - & - & - & - & - \\
\hline $\begin{array}{l}\text { Bed } \\
\text { elevation }\end{array}$ & - & - & - & - & - & - & - & - & - & - & - \\
\hline $\begin{array}{l}\text { Low cord to } \\
\text { bed length }\end{array}$ & - & - & - & - & - & - & - & - & - & - & - \\
\hline
\end{tabular}

Source (FEMA, VTAOT, Other)?

Comments: NO CROSS SECTION INFORMATION

\begin{tabular}{|l|l|l|l|l|l|l|l|l|l|l|l|}
\hline Station & - & - & - & - & - & - & - & - & - & - & - \\
\hline Feature & - & - & - & - & - & - & - & - & - & - & - \\
\hline $\begin{array}{l}\text { Low cord } \\
\text { elevation }\end{array}$ & - & - & - & - & - & - & - & - & - & - & - \\
\hline $\begin{array}{l}\text { Bed } \\
\text { elevation }\end{array}$ & - & - & - & - & - & - & - & - & - & - & - \\
\hline $\begin{array}{l}\text { Low cord to } \\
\text { bed length }\end{array}$ & - & - & - & - & - & - & - & - & - & - & - \\
\hline Station & - & - & - & - & - & - & - & - & - & - & - \\
\hline Feature & - & - & - & - & - & - & - & - & - & - & - \\
\hline $\begin{array}{l}\text { Low cord } \\
\text { elevation }\end{array}$ & - & - & - & - & - & - & - & - & - & - & - \\
\hline $\begin{array}{l}\text { Bed } \\
\text { elevation }\end{array}$ & - & - & - & - & - & - & - & - & - & - & - \\
\hline $\begin{array}{l}\text { Low cord to } \\
\text { bed length }\end{array}$ & - & - & - & - & - & - & - & - & - & - & - \\
\hline
\end{tabular}




\section{APPENDIX E: \\ LEVEL I DATA FORM}


U. S. Geological Survey

Bridge Field Data Collection and Processing Form

Qa/Qc Check by: EW

Date: $2 / 16 / 96$

Computerized by: $\underline{\mathbf{E W}}$ Date: $\underline{2 / 16 / 96}$

Structure Number CONCTH00010037

Reviewd by: SAO Date: $\underline{12 / 3 / 96}$

\section{A. General Location Descriptive}

1. Data collected by (First Initial, Full last name) R. HAMMOND

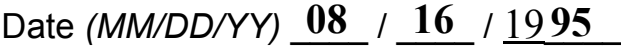

2. Highway District Number 7

Mile marker 001190

County ESSEX 009

Town CONCORD 15250

Waterway (I - 6) MOOSE RIVER

Route Number TH1

Road Name -

3. Descriptive comments:

Hydrologic Unit Code: $\mathbf{0 1 0 8 0 1 0 2}$

FEDERAL AID SYSTEM 277, 1.2 MILES FROM JCT WITH US2

VERMONT PLATE ON DS BRIDGE CURB- STATE BRIDGE NUMBER 26

\section{B. Bridge Deck Observations}
4. Surface cover... LBUS 5
RBUS 6
LBDS 6
RBDS 6
Overall 6

(2b us,ds,lb,rb: 1- Urban; 2- Suburban; 3- Row crops; 4- Pasture; 5- Shru $b$ - and brushland; 6- Forest; 7- Wetland)
5. Ambient water surface... US $\underline{2}$
UB 2
DS 2
(1- pool; 2- riffle)

6. Bridge structure type 1 (1- single span; 2- multiple span; 3- single arch; 4- multiple arch; 5-cylindrical culvert;

\section{6 -box culvert, or 7- other)}

7. Bridge length 78 (feet)

Span length $\mathbf{7 5}$

(feet)

Bridge width 21.0 (feet)

\section{Road approach to bridge:}
8. LB 1
RB 2
( 0 even, 1- lower, 2- higher)
9. LB_ 1 RB 1
(1-Paved, 2- Not paved)

10. Embankment slope (run / rise in feet / foot):

US left

US right

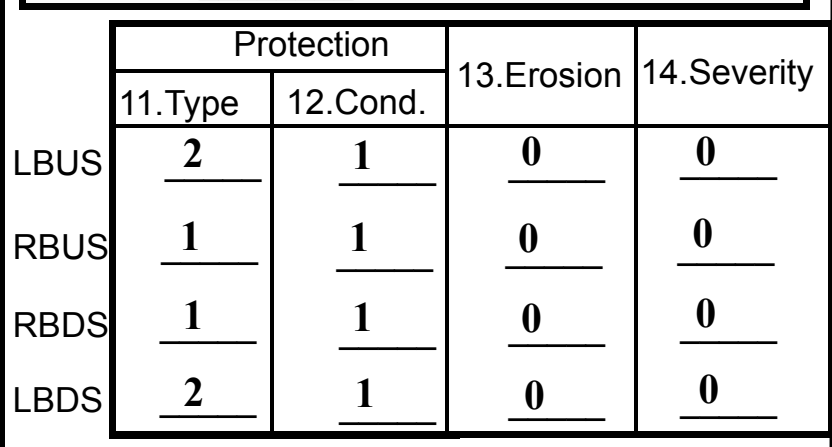

Bank protection types: 0- none; 1- < 12 inches;

2- < 36 inches; 3- < 48 inches;

4- < 60 inches; 5- wall / artificial levee

Bank protection conditions: 1- good; 2- slumped;

3- eroded; 4- failed

Erosion: 0 - none; 1- channel erosion; 2-

road wash; 3- both; 4- other

Erosion Severity: 0 - none; 1- slight; 2- moderate; 3- severe

\section{Channel approach to bridge (BF):}

15. Angle of approach: $\mathbf{0}$

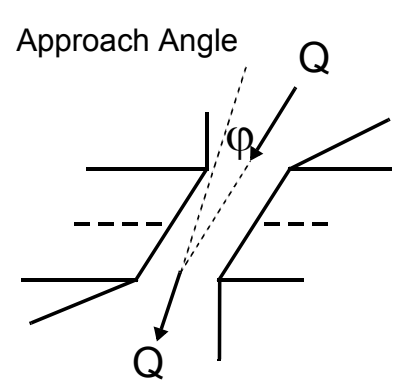

17. Channel impact zone 1:

Where? LB (LB, RB)

Range? 20

Channel impact zone 2:

Where? RB (LB, RB)

Range? $\underline{75}$ feet $\underline{\text { DS }}$

Impact Severity: 0- none to very slight; 1- Slight; 2- Moderate; 3- Severe

16. Bridge skew: $\mathbf{0}$

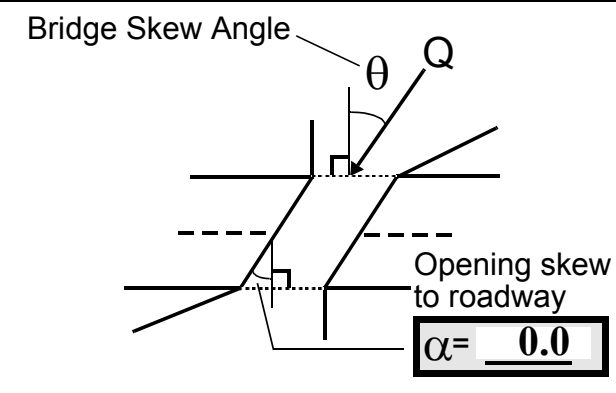

Exist? $\underline{\mathbf{Y}}(\mathrm{Y}$ or $N)$

Severity 1

US, UB, DS) to $\underline{\mathbf{1 0}}$ feet $\underline{\mathbf{U S}}$

Exist? $\mathbf{Y}(Y$ or $N)$

Severity $\underline{3}$

, UB, DS) to $\underline{\mathbf{2 0 0}}$ feet $\underline{\mathbf{D S}}$ 
18. Bridge Type: 1a

1a- Vertical abutments with wingwalls

1 b- Vertical abutments without wingwalls

2- Vertical abutments and wingwalls, sloping embankment

Wingwalls perpendicular to abut. face

3- Spill through abutments

4- Sloping embankment, vertical wingwalls and abutments

Wingwall angle less than $90^{\circ}$.

1a with wingwalls

19. Bridge Deck Comments (surface cover variations, measured bridge and span lengths, bridge type variations, approach overflow width, etc.)

\#15 and \#16: The US channel bends in from the LB then straightens into bridge. The channel bends to the left after exiting the bridge

\section{Upstream Channel Assessment}

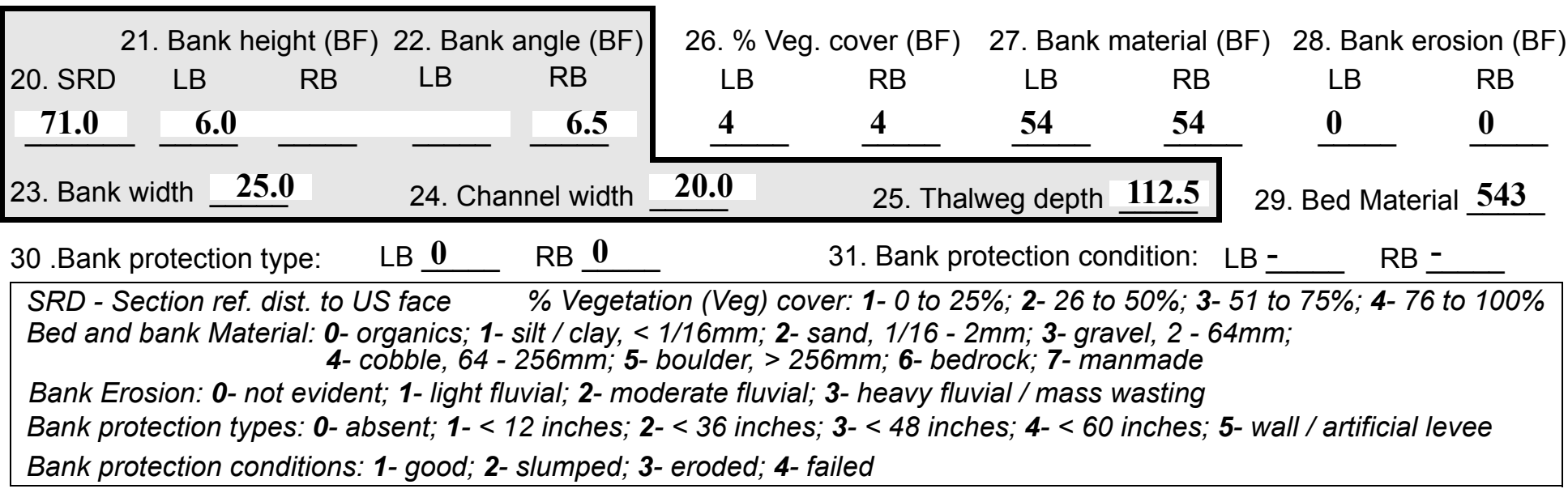

32. Comments (bank material variation, minor inflows, protection extent, etc.):

\#30 and \#31: bank protection from ends of wingwalls extends 35 feet US, LB and RB- good condition 
33.Point/Side bar present? $\mathbf{N}(Y$ or $N$. if $N$ type ctrl-n pb)34. Mid-bar distance: -

35. Mid-bar width: -

36. Point bar extent: feet (US, UB) to feet (US, UB, DS) positioned $\%$ LB to $\% \mathrm{RB}$

37. Material:

38. Point or side bar comments (Circle Point or Side; Note additional bars, material variation, status, etc.):

NO POINT BARS

Mid-channel bar due to bedrock outcrop starting 190 feet US to 135 feet US

Mid-channel bar 135 feet US to 20 feet US

39. Is a cut-bank present? $\mathbf{N}$ (Y or if $N$ type ctrl-n cb)

40. Where? (LB or $R B)$

41. Mid-bank distance: -

42. Cut bank extent: feet (US, UB) to feet (US, UB, DS)

43. Bank damage: (1- eroded and/or creep; 2- slip failure; 3- block failure)

44. Cut bank comments (eg. additional cut banks, protection condition, etc.):

NO CUT BANKS

45. Is channel scour present? $\mathbf{N}$ ( $Y$ or if $N$ type ctrl-n cs)

47. Scour dimensions: Length Width Depth : 46. Mid-scour distance: -

48. Scour comments (eg. additional scour areas, local scouring process, etc.):

NO CHANNEL SCOUR

local scour behind many boulders and along side of bedrock outcrop

49. Are there major confluences? $\mathbf{Y}$ (Y or if $N$ type ctrl-n $m c$ )

51. Confluence 1: Distance 47

Confluence 2: Distance

52. Enters on $\underline{\mathbf{R B}}$ ( $L B$ or $R B)$

Enters on (LB or RB)

54. Confluence comments (eg. confluence name):

\#53: flowing during visit

\section{Under Bridge Channel Assessment}

55. Channel restraint (BF)? LB 2

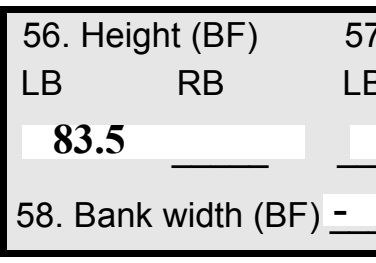

59. Channel width (Amb) -

61. Material $(\mathrm{BF})$

LB RB

$\underline{2} \quad \underline{7}$

\section{0}

50. How many? 1

53. Type 1 (1-perennial; 2- ephemeral)

Type (1-perennial; 2-ephemeral)

Bed and bank Material: 0- organics; 1- silt / clay, < 1/16mm; 2- sand, 1/16 - 2mm; 3- gravel, 2 - 64mm; 4- cobble, 64 - 256mm; 5- boulder, > 256mm; 6- bedrock; 7- manmade

Bank Erosion: 0- not evident; 1- light fluvial; 2- moderate fluvial; 3- heavy fluvial / mass wasting

64. Comments (bank material variation, minor inflows, protection extent, etc.):

543

\#62: LB abutment and footing exposed but is protected by large boulders 
65. Debris and Ice Is there debris accumulation?

(Yor $N)$ 66. Where? $\underline{Y}$

(1- Upstream; 2- At bridge; 3- Both)

67. Debris Potential 1 (1-Low; 2- Moderate; 3- High)

68. Capture Efficiency 1

(1-Low; 2- Moderate; 3- High)

69. Is there evidence of ice build-up? 1 ( $Y$ or $N)$

Ice Blockage Potential $\mathbf{N}$

(1- Low; 2- Moderate; 3- High)

70. Debris and Ice Comments:

1

\#65: small debris on $\mathrm{LB}$ above bridge

\begin{tabular}{|l|c|c|c|c|c|c|c|c|}
\hline Abutments & $\begin{array}{c}\text { 71. Attack } \\
\angle \mathrm{BF})\end{array}$ & $\begin{array}{c}\text { 72. Slope } \\
(\mathrm{Qmax})\end{array}$ & $\begin{array}{l}\text { 73. Toe } \\
\text { loc. (BF) }\end{array}$ & $\begin{array}{c}\text { 74. Scour } \\
\text { Condition }\end{array}$ & $\begin{array}{c}\text { 75. Scour } \\
\text { depth }\end{array}$ & $\begin{array}{c}\text { 76. Exposure } \\
\text { depth }\end{array}$ & 77. Material & 78. Length \\
\hline LABUT & & $\mathbf{0}$ & $\mathbf{9 0}$ & $\mathbf{2}$ & $\mathbf{2}$ & $\mathbf{0}$ & $\mathbf{4}$ & $\mathbf{9 0 . 0}$ \\
\hline RABUT & $\mathbf{1}$ & $\mathbf{0}$ & $\mathbf{9 0}$ & & & $\mathbf{2}$ & $\mathbf{2}$ & $\mathbf{7 1 . 0}$ \\
\hline
\end{tabular}

Pushed: $L B$ or RB

Toe Location (Loc.): 0- even, 1- set back, 2- protrudes

Scour cond.: 0- not evident; 1- evident (comment); 2- footing exposed; 3-undermined footing; 4- piling exposed; 5- settled; 6- failed

Materials: 1- Concrete; 2- Stone masonry or drywall; 3- steel or metal; 4- wood

79. Abutment comments (eg. undermined penetration, unusual scour processes, debris, etc.):

$\mathbf{0}$

1.5

1

\#76: RB footing exposed max. 1.5 feet- DS buried

LB footing exposed max. 4 feet- minimum 1 foot (both ends)

80. Wingwalls:

Exist? Material? Scour Scour Exposure Angle? Length? Condition? depth? depth?

USLWW:

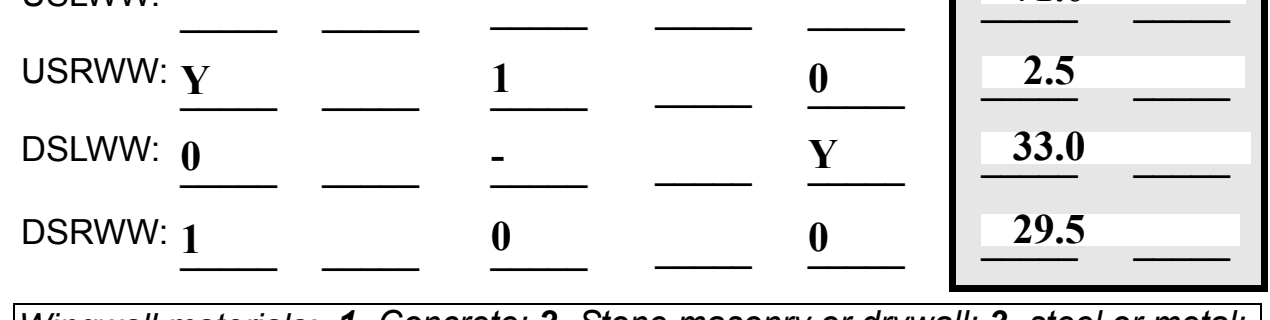

Wingwall materials: 1- Concrete; 2- Stone masonry or drywall; 3- steel or metal; 4- wood

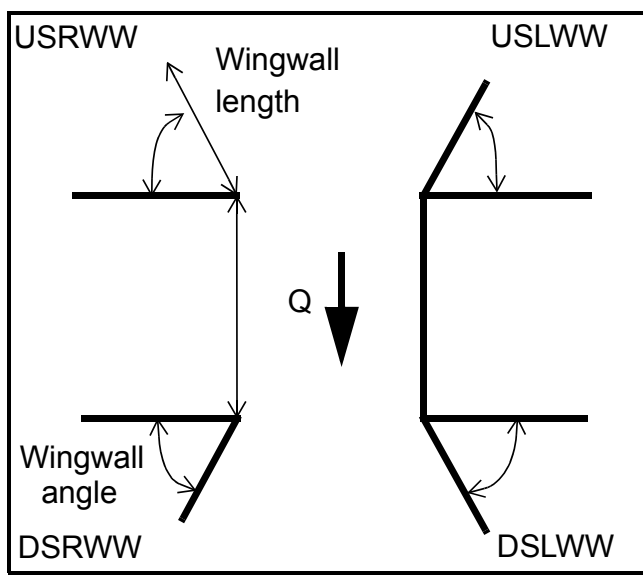

82. Bank / Bridge Protection:

\begin{tabular}{|l|l|l|l|l|l|l|l|l|}
\hline Location & USLWW & USRWW & LABUT & RABUT & LB & RB & DSLWW & DSRWW \\
\hline Type & - & $\mathbf{0}$ & $\mathbf{Y}$ & $\mathbf{0}$ & $\mathbf{1}$ & $\mathbf{1}$ & $\mathbf{1}$ & - \\
\hline Condition & $\mathbf{Y}$ & $\mathbf{0}$ & $\mathbf{1}$ & - & $\mathbf{1}$ & $\mathbf{1}$ & $\mathbf{1}$ & -- \\
\hline Extent & $\mathbf{1}$ & - & $\mathbf{0}$ & $\mathbf{3}$ & $\mathbf{2}$ & $\mathbf{4}$ & $\mathbf{0}$ & \\
\hline
\end{tabular}

Bank / Bridge protection types: 0- absent; 1- < 12 inches; 2- < 36 inches; 3- < 48 inches; 4- < 60 inches; 
83. Wingwall and protection comments (eg. undermined penetration, unusual scour processes, etc.):

1
1
1
1
1
1

Piers:

84. Are there piers? _ ( $Y$ or if $N$ type ctrl-n pr)

\begin{tabular}{|l|l|l|l|l|l|l|l|}
\hline \multirow{2}{*}{$\begin{array}{l}85 . \\
\text { Pier no. }\end{array}$} & \multicolumn{3}{|c|}{ width (w) feet } & \multicolumn{3}{c|}{ elevation (e) feet } \\
\cline { 2 - 8 } & w1 & w2 & w3 & e@w1 & e@w2 & e@w3 \\
\hline Pier 1 & & & & $\mathbf{3 5 . 0}$ & $\mathbf{1 1 . 0}$ & $\mathbf{6 0 . 0}$ \\
\hline Pier 2 & & & & $\mathbf{1 3 . 5}$ & $\mathbf{1 8 0 . 0}$ & $\mathbf{1 3 . 0}$ \\
\hline Pier 3 & & $\mathbf{7 . 0}$ & - & $\mathbf{7 0 . 0}$ & - & - \\
\hline Pier 4 & - & - & - & - & - & - \\
\hline
\end{tabular}

\begin{tabular}{|c|c|c|c|c|}
\hline Level 1 Pier Descr. & 1 & 2 & 3 & 4 \\
\hline 86. Location (BF) & & - & - & - \\
\hline 87. Type & & - & - & - \\
\hline 88. Material & & - & - & - \\
\hline 89. Shape & & - & - & - \\
\hline 90. Inclined? & & - & - & - \\
\hline 91. Attack $\angle(B F)$ & & - & - & - \\
\hline 92. Pushed & & - & - & - \\
\hline 93. Length (feet) & - & - & - & - \\
\hline 94. \# of piles & & - & - & - \\
\hline 95. Cross-members & & - & - & - \\
\hline 96. Scour Condition & & - & - & - \\
\hline 97. Scour depth & $\mathbf{N}$ & - & - & - \\
\hline 98. Exposure depth & - & - & - & - \\
\hline
\end{tabular}

LFP, LTB, LB, MCL, MCM, MCR, RB, RTB, RFP

1- Solid pier, 2- column, 3- bent

1-Wood; 2- concrete; 3- metal; 4- stone

1- Round; 2- Square; 3- Pointed

Y-yes; $N$ - no

$L B$ or $R B$

0- none; 1- laterals; 2- diagonals; 3- both

0- not evident; 1- evident (comment);

2- footing exposed; 3- piling exposed;

4- undermined footing; 5- settled; 6 - failed 
99. Pier comments (eg. undermined penetration, protection and protection extent, unusual scour processes, etc.):

-
-
-
-
-
-
-
-
-
-

100.

\section{E. Downstream Channel Assessment}

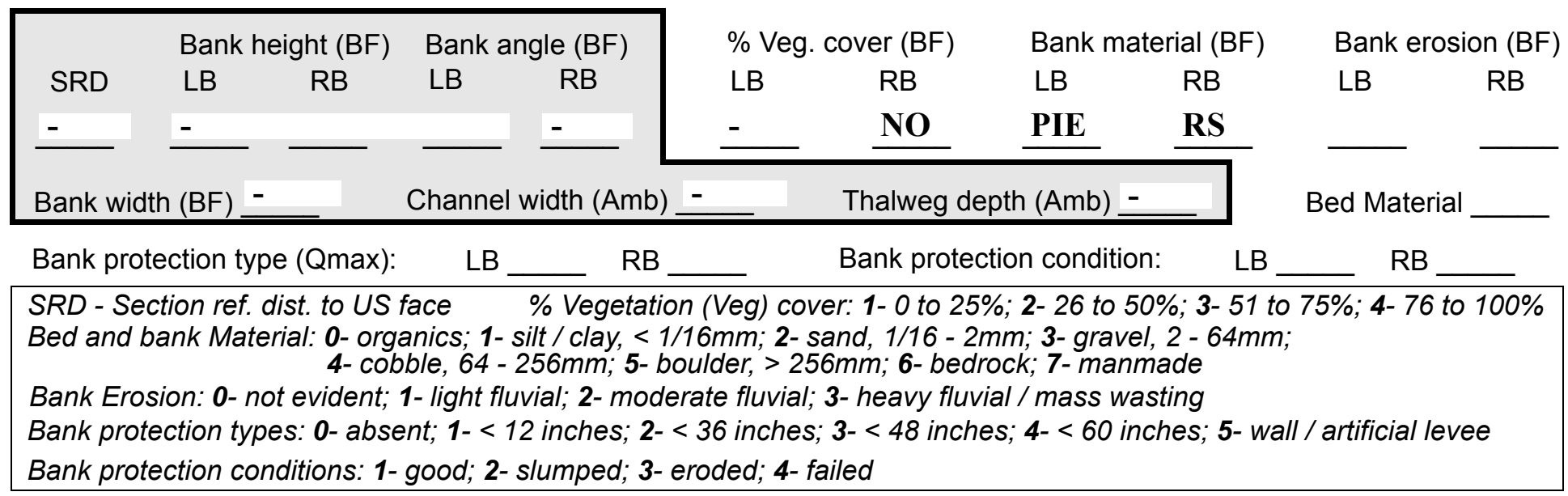

Comments (eg. bank material variation, minor inflows, protection extent, etc.):

$\mathbf{4}$
$\mathbf{4}$
$\mathbf{5 4}$
$\mathbf{5 4}$
$\mathbf{0}$
$\mathbf{0}$
$\mathbf{5 4}$
$\mathbf{0}$
$\mathbf{0}$
-
-

Bank protection at ends of wingwalls extends to 20 feet DS on RB and LB

101. Is a drop structure present? ___ ( or $N$, if $N$ type ctrl-n ds) 102. Distance: ___ feet

103. Drop: ___ feet 104. Structure material:___ (1- steel sheet pile; 2- wood pile; 3- concrete; 4- other)

105. Drop structure comments (eg. downstream scour depth): 
Point bar extent: feet

(US, UB, DS) to $\underline{\mathbf{N}}$ feet (US, UB, DS)

DS) positioned \%LB to DR \%RB

Material: $\mathbf{O P}$

Point or side bar comments (Circle Point or Side; note additional bars, material variation, status, etc.):

\section{STRUCTURE}

Is a cut-bank present? (Y or if $N$ type ctrl- $n$ cb) Where? (LB or $R B)$

Mid-bank distance: $\underline{\mathbf{Y}}$ Cut bank extent: $\underline{\mathbf{2 0 0}}$ feet $\underline{\mathbf{1 5}}$ (US, UB, DS) to $\underline{\mathbf{7 5}}$ feet $\underline{\mathrm{DS}}$ (US, UB, DS)

Bank damage: 250 (1- eroded and/or creep; 2- slip failure; 3- block failure)

Cut bank comments (eg. additional cut banks, protection condition, etc.):

DS

$\mathbf{0}$

25

45

Is channel scour present? poi ( $Y$ or if $N$ type ctrl-n cs) Mid-scour distance: $\underline{\text { nt }}$ Scour dimensions: Length bar Width Depth:

Positioned $\%$ LB to $\underline{\mathbf{Y}} \% \mathrm{RB}$

Scour comments (eg. additional scour areas, local scouring process, etc.):

RB

175

100

DS

Are there major confluences? $\mathbf{2 0}$ ( $Y$ or if $N$ type ctrl-n $m c$ )

How many? $\underline{0}$

Confluence 1: Distance DS

Enters on $\underline{1}$ (LB or RB)

Type mos (1- perennial; 2- ephemeral)

Confluence 2: Distance tly

Enters on was (LB or RB)

Type hing (1- perennial; 2- ephemeral)

Confluence comments (eg. confluence name):

off dirt and soil from between large boulders

\section{F. Geomorphic Channel Assessment}

107. Stage of reach evolution

1- Constructed

2- Stable

3- Aggraded

4- Degraded

5- Laterally unstable

6- Vertically and laterally unstable 
108. Evolution comments (Channel evolution not considering bridge effects; See HEC-20, Figure 1 for geomorphic descriptors):

$\mathbf{N}$

$-$

$-$

$-$

$-$

$-$

NO CHANNEL SCOUR

local scour behind large boulders and between boulders where flow constriction occurs N 


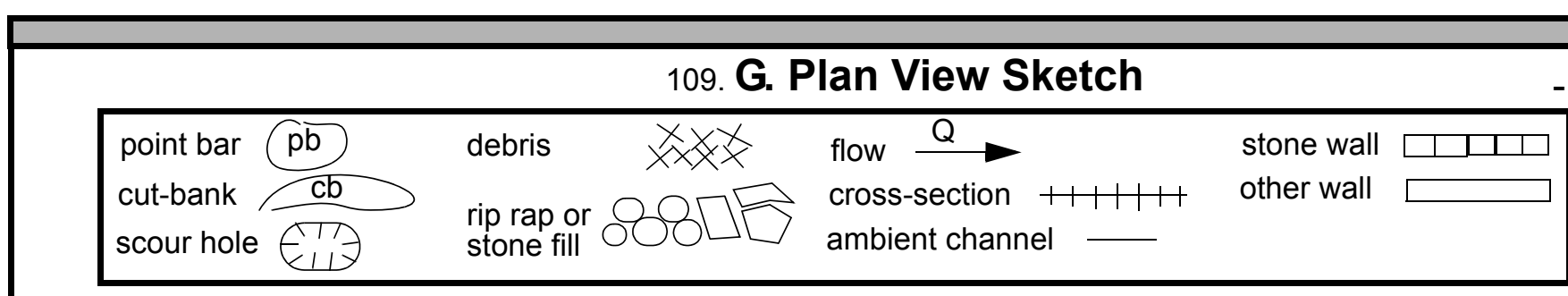


APPENDIX F:

SCOUR COMPUTATIONS 
SCOUR COMPUTATIONS

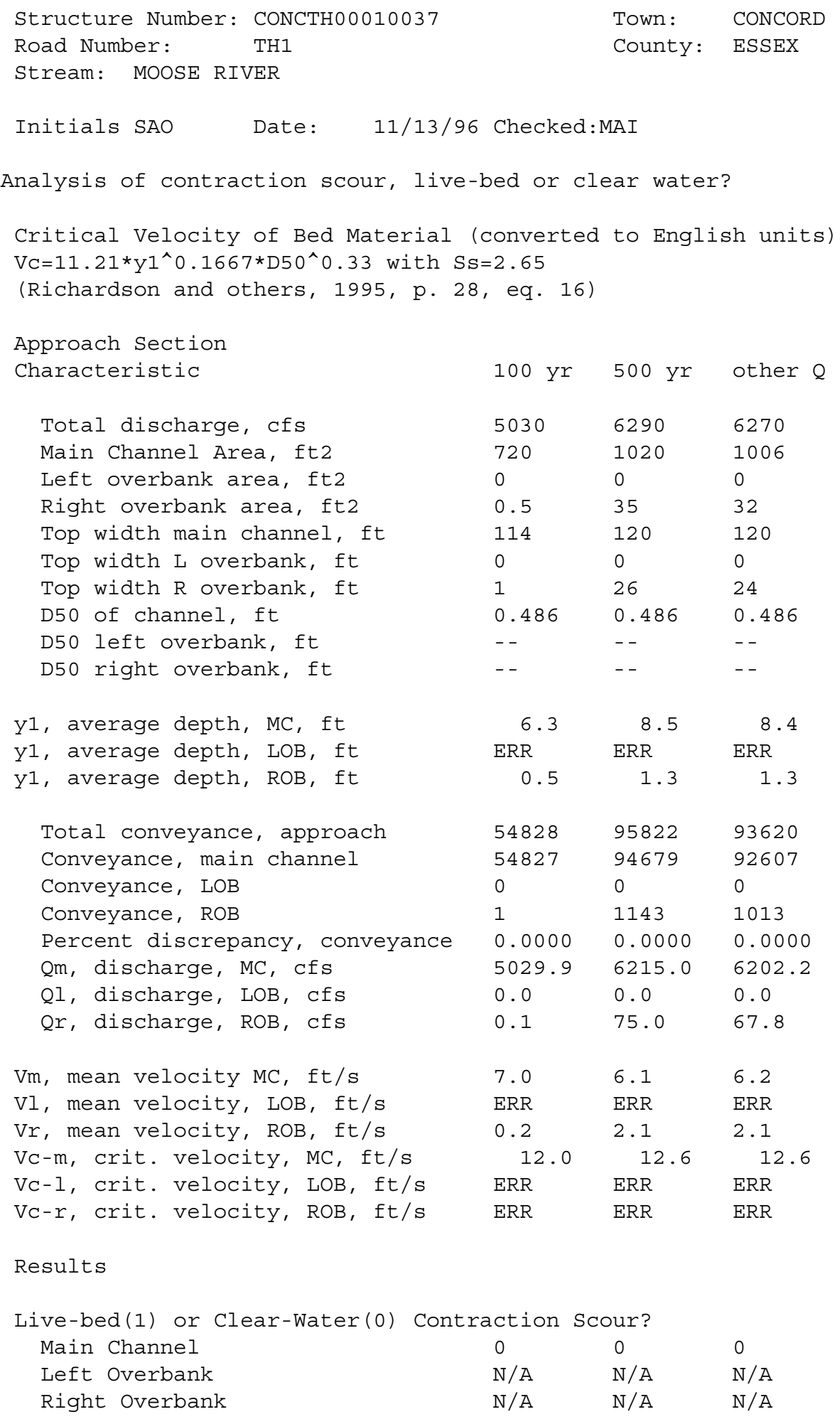




\begin{tabular}{|c|c|c|c|}
\hline \multicolumn{4}{|l|}{ ARMORING } \\
\hline D90 & 2.474 & 2.474 & 2.474 \\
\hline D95 & 3.327 & 3.327 & 3.327 \\
\hline Critical grain size,Dc, ft & 1.3830 & 0.6598 & 0.6577 \\
\hline Decimal-percent coarser than Dc & 0.238 & 0.436 & 0.437 \\
\hline Depth to armoring, ft & 13.28 & 2.56 & 2.54 \\
\hline
\end{tabular}

Clear water Contraction Scour in MAIN CHANNEL

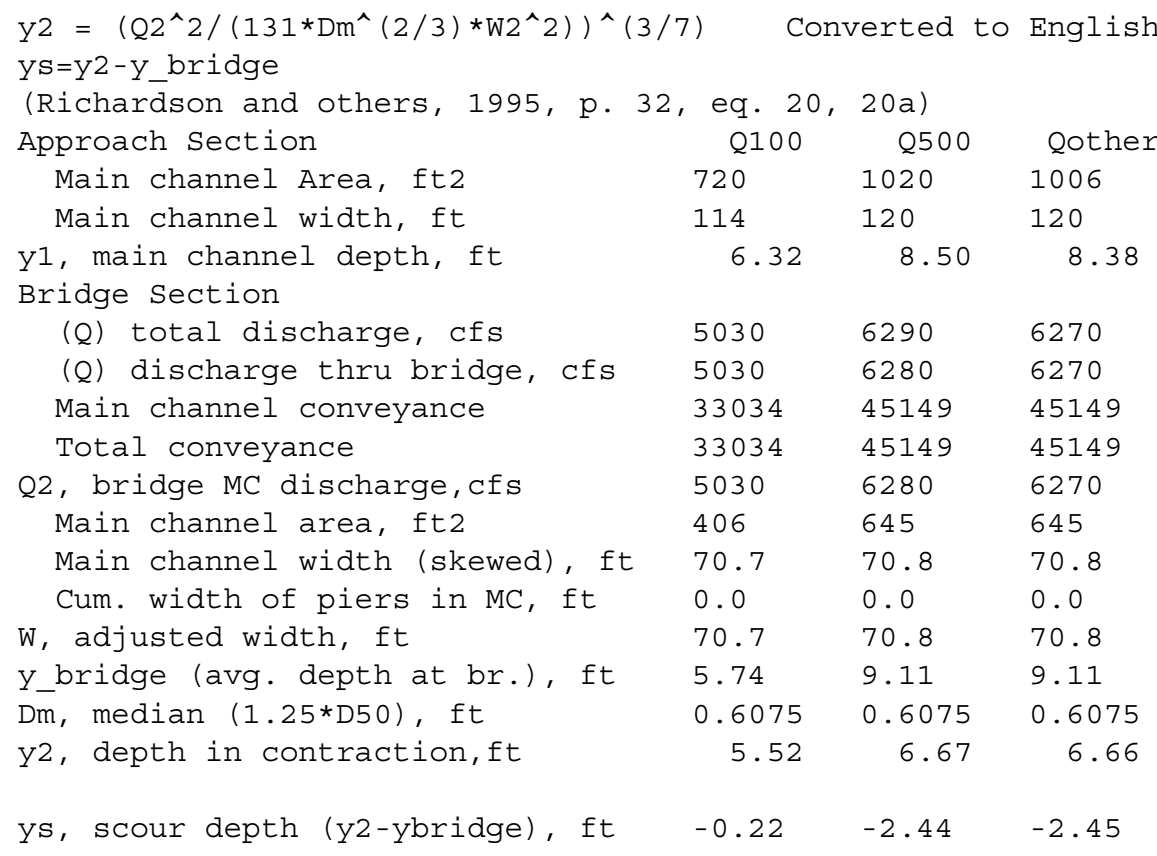

Pressure Flow Scour (contraction scour for orifice flow conditions)

\begin{tabular}{|c|c|c|c|c|}
\hline $\mathrm{Hb}+\mathrm{Ys}=\mathrm{Cq} * \mathrm{qbr} / \mathrm{Vc}$ & & $\mathrm{Cf}=1.5$ & $\cong 0.43$ & $(<=1)$ \\
\hline $\begin{array}{l}\text { Chang Equation } \quad \text { CC=SQRT }[0.10 \\
\text { (Richarson and others, 1995, p. 145 }\end{array}$ & $\begin{array}{l}(\mathrm{Hb} /(\mathrm{y} \\
-146)\end{array}$ & v) -0.56 & 0.79 & $(<=1)$ \\
\hline & Q100 & Q500 & OtherQ & \\
\hline Q, total, cfs & 5030 & 6290 & 6270 & \\
\hline Q, thru bridge, cfs & 5030 & 6280 & 6270 & \\
\hline Total Conveyance, bridge & 33034 & 45149 & 45149 & \\
\hline Main channel (MC) conveyance, bridge & 33034 & 45149 & 45149 & \\
\hline Q, thru bridge $\mathrm{MC}$, Cfs & 5030 & 6280 & 6270 & \\
\hline Vc, critical velocity, ft/s & 11.98 & 12.59 & 12.56 & \\
\hline Vc, critical velocity, m/s & 3.65 & 3.84 & 3.83 & \\
\hline Main channel width (skewed), ft & 70.7 & 70.8 & 70.8 & \\
\hline Cum. width of piers in MC, ft & 0.0 & 0.0 & 0.0 & \\
\hline W, adjusted width, ft & 70.7 & 70.8 & 70.8 & \\
\hline qbr, unit discharge, $f t^{\wedge} 2 / \mathrm{s}$ & 71.1 & 88.7 & 88.6 & \\
\hline qbr, unit discharge, $\mathrm{m}^{\wedge} 2 / \mathrm{s}$ & 6.6 & 8.2 & 8.2 & \\
\hline Area of full opening, $\mathrm{ft}^{\wedge} 2$ & 406.0 & 645.0 & 645.0 & \\
\hline $\mathrm{Hb}$, depth of full opening, ft & 5.74 & 9.11 & 9.11 & \\
\hline Hb, depth of full opening, m & 1.75 & 2.78 & 2.78 & \\
\hline Fr, Froude number, bridge MC & 0 & 0.57 & 0.56 & \\
\hline Cf $\operatorname{Fr}$ correction factor $(<=1.0)$ & 0.00 & 1.00 & 1.00 & \\
\hline
\end{tabular}




\begin{tabular}{|c|c|c|c|}
\hline Elevation of Low Steel, ft & 0 & 896.79 & 896.79 \\
\hline Elevation of Bed, ft & -5.74 & 887.68 & 887.68 \\
\hline Elevation of Approach, ft & 0 & 899.42 & 899.3 \\
\hline Friction loss, approach, ft & 0 & 0.58 & 0.6 \\
\hline Elevation of WS immediately US, ft & 0.00 & 898.84 & 898.70 \\
\hline ya, depth immediately US, ft & 5.74 & 11.16 & 11.02 \\
\hline ya, depth immediately US, m & 1.75 & 3.40 & 3.36 \\
\hline Mean elevation of deck, ft & 0 & 900.98 & 900.98 \\
\hline w, depth of overflow, ft $(>=0)$ & 0.00 & 0.00 & 0.00 \\
\hline Cc, vert contrac correction $(<=1.0)$ & 1.00 & 0.95 & 0.95 \\
\hline Ys, depth of scour, ft & 0.00 & -1.70 & -1.71 \\
\hline Comparison of Chang and Laursen res & alts (for & unsubmerg & yed orifice flow) \\
\hline Y2, from Laursen's equation, ft & 5.520747 & 6.669498 & 6.660394 \\
\hline Full valley WSEL, ft & 0 & 895.15 & 895.15 \\
\hline Full valley depth, ft & 5.742574 & 7.470169 & 7.470169 \\
\hline Ys, depth of scour (y2-yfullv), ft & 0 & -0.80067 & -0.80978 \\
\hline
\end{tabular}

Abutment Scour

Froehlich's Abutment Scour

$\mathrm{Ys} / \mathrm{Y} 1=2.27 * \mathrm{~K} 1 * \mathrm{~K} 2 *\left(\mathrm{a}^{\prime} / \mathrm{Y} 1\right)^{\wedge} 0.43 * \mathrm{Fr} 1^{\wedge} 0.61+1$

(Richardson and others, 1995, p. 48, eq. 28)

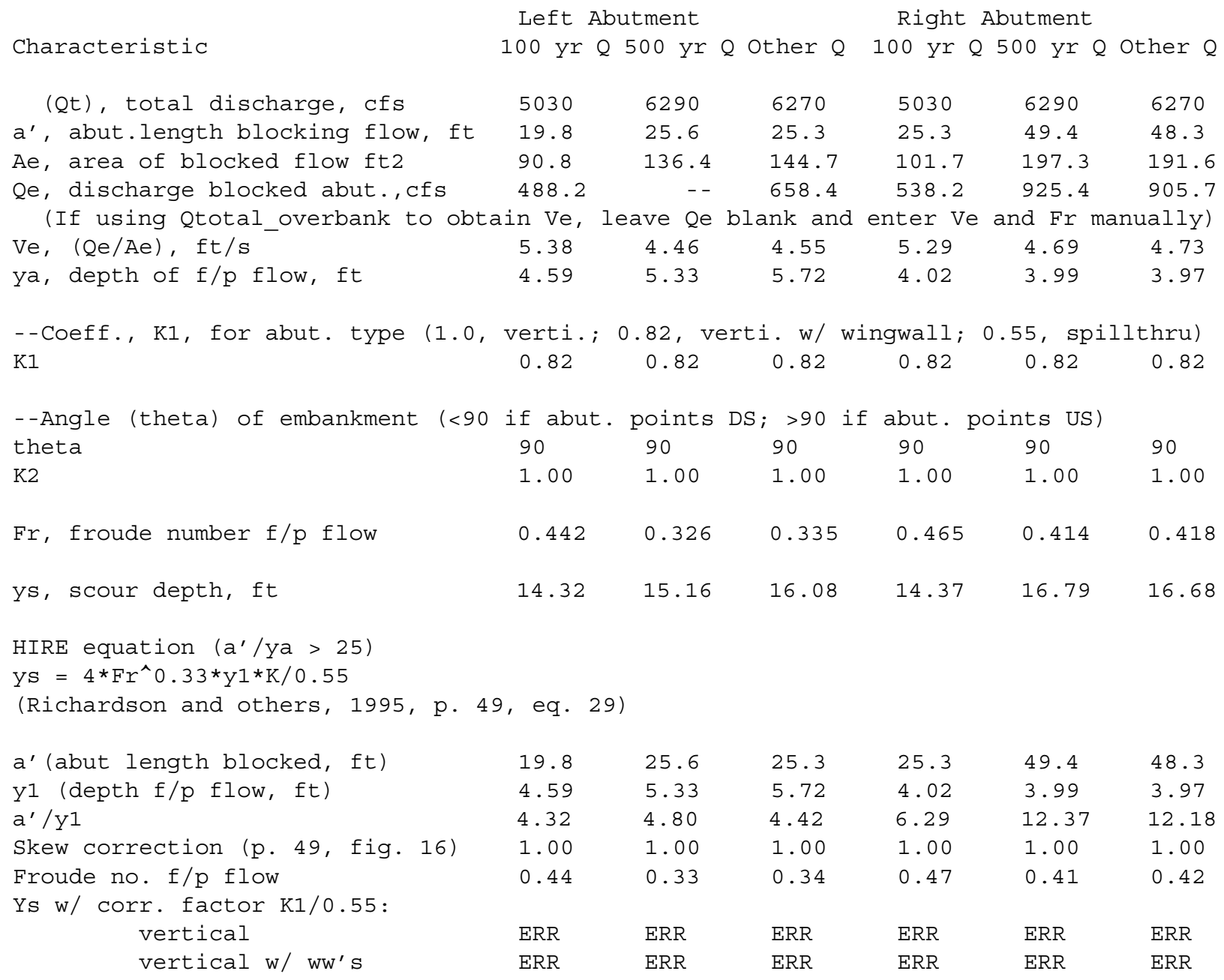




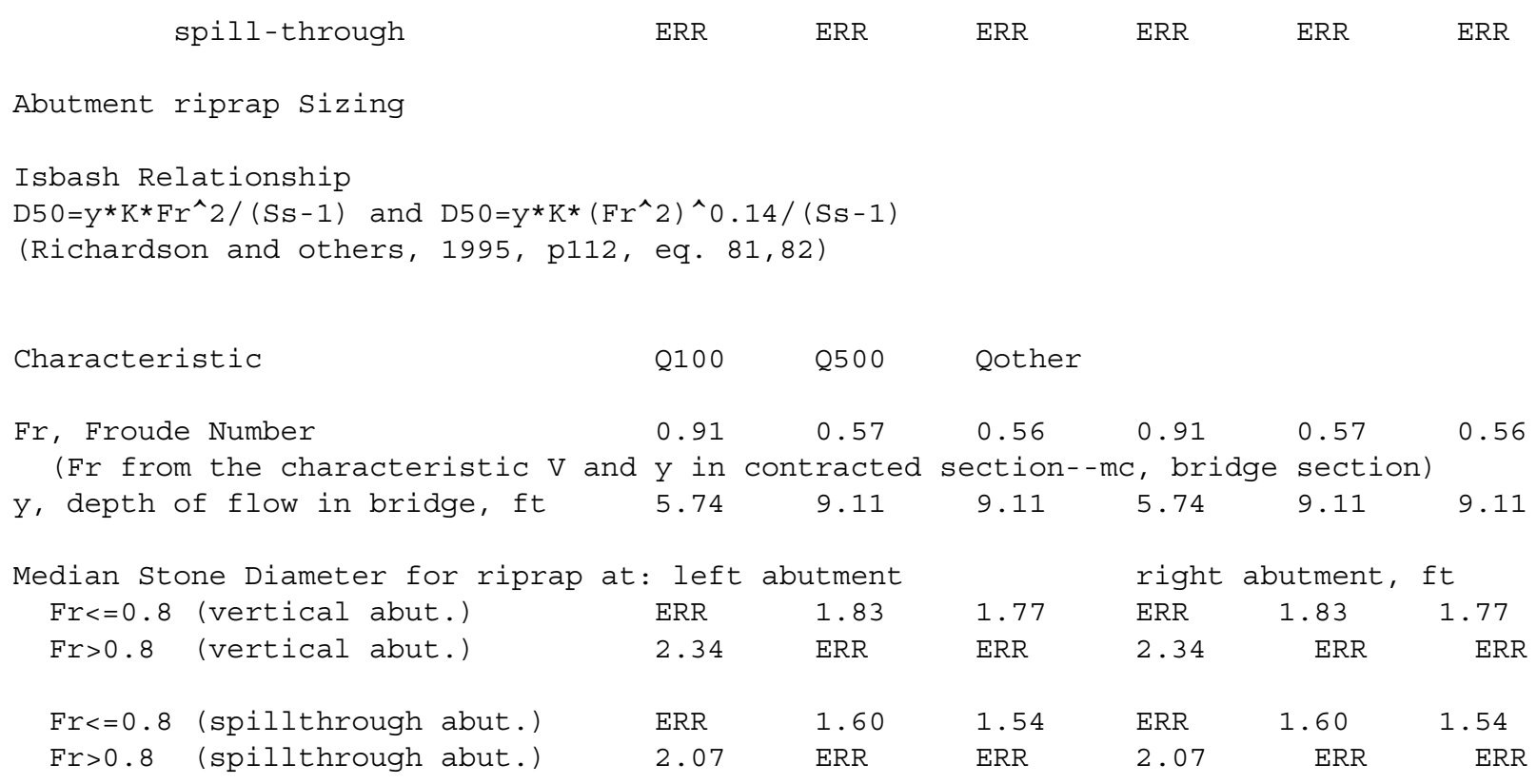

